\title{
Papers
}

\section{Reduction of postoperative mortality and morbidity with epidural or spinal anaesthesia: results from overview of randomised trials}

Anthony Rodgers, Natalie Walker, S Schug, A McKee, H Kehlet, A van Zundert, D Sage, M Futter, G Saville, T Clark, S MacMahon

\begin{abstract}
Objectives To obtain reliable estimates of the effects of neuraxial blockade with epidural or spinal

anaesthesia on postoperative morbidity and mortality. Design Systematic review of all trials with randomisation to intraoperative neuraxial blockade or not.

Studies 141 trials including 9559 patients for which data were available before 1 January 1997. Trials were eligible irrespective of their primary aims, concomitant use of general anaesthesia, publication status, or language. Trials were identified by extensive search methods, and substantial amounts of data were obtained or confirmed by correspondence with trialists.

Main outcome measures All cause mortality, deep vein thrombosis, pulmonary embolism, myocardial infarction, transfusion requirements, pneumonia, other infections, respiratory depression, and renal failure.

Results Overall mortality was reduced by about a third in patients allocated to neuraxial blockade (103 deaths/4871 patients versus $144 / 4688$ patients, odds ratio $=0.70,95 \%$ confidence interval 0.54 to 0.90 , $\mathrm{P}=0.006)$. Neuraxial blockade reduced the odds of deep vein thrombosis by $44 \%$, pulmonary embolism by $55 \%$, transfusion requirements by $50 \%$, pneumonia by $39 \%$, and respiratory depression by $59 \%$ (all $\mathrm{P}<0.001)$. There were also reductions in myocardial infarction and renal failure. Although there was limited power to assess subgroup effects, the proportional reductions in mortality did not clearly differ by surgical group, type of blockade (epidural or spinal), or in those trials in which neuraxial blockade was combined with general anaesthesia compared with trials in which neuraxial blockade was used alone.

Conclusions Neuraxial blockade reduces postoperative mortality and other serious complications. The size of some of these benefits remains uncertain, and further research is required to determine whether these effects are due solely to benefits of neuraxial blockade or partly to avoidance of general anaesthesia. Nevertheless, these findings support more widespread use of neuraxial blockade.
\end{abstract}

\section{Introduction}

Anaesthesia is commonly classified into two main techniques: general anaesthesia, in which gaseous or intravenous drugs achieve central neurological depression, and regional anaesthesia, in which drugs are administered directly to the spinal cord or nerves to locally block afferent and efferent nerve input. ${ }^{1}$ Regional anaesthesia for major thoracic, abdominal, or leg surgery relies on neuraxial blockade by injection of local anaesthetic drugs into either the subarachnoid space (spinal anaesthesia) or into the epidural space surrounding the spinal fluid sac (epidural anaesthesia).

The risks of fatal or life threatening events are increased several fold after major surgery, but there is debate about whether the type of anaesthesia has any substantive effect on these risks. Neuraxial blockade has several physiological effects that provide a rationale for expecting to improve outcome with this technique. ${ }^{2}$ However, the few clinical trials of epidural or spinal anaesthesia that have focused specifically on fatal or life threatening events have generally been too small to detect effects of plausible size reliably. To provide more reliable estimates of the effects of neuraxial blockade on postoperative morbidity and mortality, we conducted a systematic review of all relevant randomised trials.

\section{Methods}

\section{Identification of trials and data collection}

We sought to identify all trials in which patients were randomised to receive intraoperative neuraxial blockade (with epidural or spinal anaesthesia) or not. We did not exclude trials in adult populations in which the group receiving neuraxial blockade group also received general anaesthesia, the general anaesthesia group received postoperative neuraxial blockade, or there was more than one type of neuraxial blockade or general anaesthesia group (in which case similar groups were combined). Eligibility was not based on whether results were published, the language of publication, or the primary aims of the trial-for example, we included a randomised trial designed to assess the effects of neuraxial blockade on cognitive function. ${ }^{3}$ Trials were ineligible if they were not randomised or

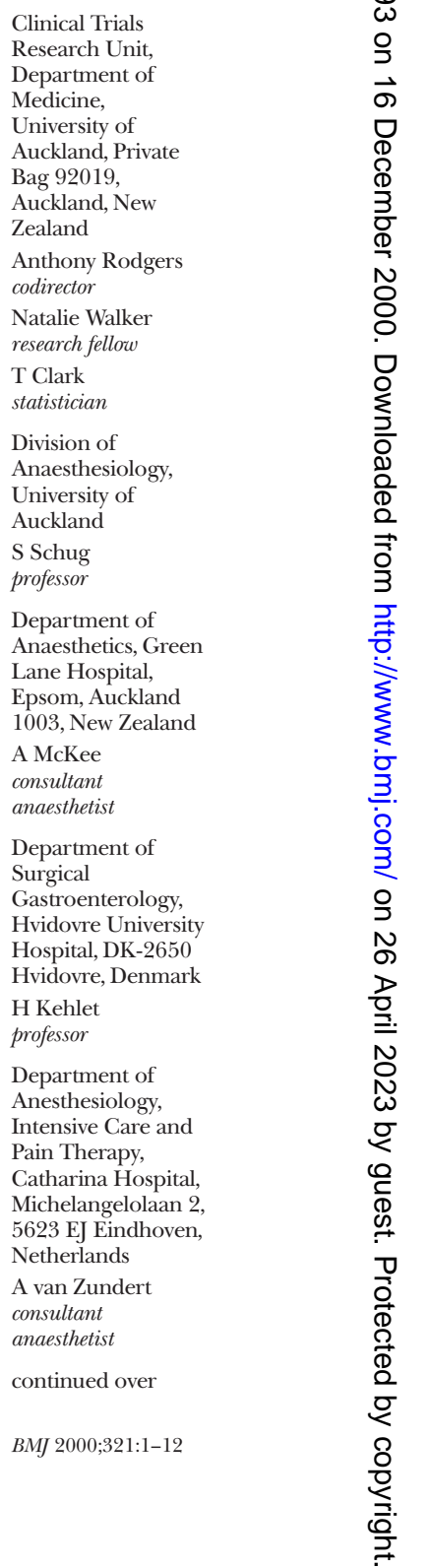


Department of Anaesthesia, Auckland and Starship Hospitals, Private Bag 92024 Auckland, New Zealand

D Sage

consultant

anaesthetist

M Futter

consultant

anaesthetist

Department of

Anaesthesia, Roya

Cornwall Hospital,

Treliske, Truro

TR1 3LJ

G Saville

consultant

anaesthetist

Institute for

International

Health, University

of Sydney, PO Box

1225, Crows Nest,

Sydney, NSW 1585 .

Australia

S MacMahon

professor

Correspondence to:

A Rodgers

a.rodgers@ctru.

auckland.ac.nz were quasi-randomised (such as assignment according to date of birth) or if data were not available before 1 January 1997.

We conducted a computerised search using the electronic databases Current Contents (1995-6), Embase (Excerpta Medica, 1980-96), Medline (196696), and the Cochrane Library (1998). We used the key words "regional anaesthesia," "regional anesthesia," "spinal," or "epidural" and the Cochrane Collaboration search terms for randomised trials. ${ }^{4}$ Once papers were identified, authors' names and study titles were used as search terms. We scrutinised the reference lists of all identified papers and also hand searched selected conference proceedings.

We developed standard data collection sheets to record details of trial design, interventions, patient characteristics, and events. We did not use quality scores because analyses stratified by specific design characteristics are more informative. ${ }^{5}$ The definitions of events were those used in the original trials, since patients in one trial were directly compared only with those in the same trial. Two reviewers independently recorded the published findings from each study. This process was not blinded. A third reviewer compared the two sets of data collection sheets and any differences were resolved by discussion. We attempted to contact the authors of all trials to verify the data and obtain additional unpublished data. If there was more than one trial report, authors were also asked whether the patient groups overlapped. Lastly, we asked authors if they knew of any other relevant studies (published or unpublished).

\section{Statistical analysis}

Analysis was carried out on an intention to treat basis wherever possible. If no events were reported in the publication or by the authors, we assumed that none occurred. This assumption will generally provide unbiased estimates of proportional effects (the entity typically combined in meta-analysis) but will underestimate absolute effects. ${ }^{6}$ We calculated odds ratios, 95\% confidence intervals, and two sided $\mathrm{P}$ values for each outcome of interest using Peto's modification of the Mantel-Haenszel method. ${ }^{7}$ Homogeneity was assessed by a $\chi^{2}$ test. Whenever possible, we stratified analyses of cause specific outcomes by surgical group and type of anaesthetic to determine whether these factors modified the size or direction of proportional effects. However, there were often too few trials with events for such analyses to be informative, and so subgroup analyses are mostly reported for the crude outcome of total mortality.

\section{Results}

\section{Study characteristics}

We identified 158 potentially eligible trials. Ten studies were excluded because they were quasi-randomised, ${ }^{8-17}$ and six were excluded because not all participants were randomised and separate information on the randomised patients was not available. ${ }^{18-23}$ One trial was excluded because the groups differed with respect to heparin treatment as well as anaesthetic technique. ${ }^{24}$ The remaining 141 trials that met all the inclusion criteria included a total of 9559 patients. ${ }^{35-192}$ More than one publication was available for 18 studies $^{46-49596062-6572738485}$ 87-92 94-96 99100106107 124-128 134135145 146 156-158 161-163173 174187188 but each study was counted only once. No unpublished eligible studies were identified.

The study authors for $107(76 \%)$ eligible trials, including $8290(87 \%)$ patients, verified the data collection sheets. In almost all cases, we obtained additional unpublished information from contacting the authors, mostly about trial design, but also about events (for example 18 deaths were not reported in original publications). Table 1 shows the patient characteristics and anaesthetic methods and tables 2 and 3 provide summary details of outcome events. We defined a neuraxial blockade group and a non-neuraxial blockade group for each trial, which necessitated collapsing similar groups in 15 trials with more than one randomised comparison. The neuraxial blockade group had no general anaesthesia in $79(56 \%)$ trials and the same general anaesthesia as the non-neuraxial blockade group in $37(26 \%)$ trials. In $22(15 \%)$ trials the neuraxial blockade group received a general anaesthesia different from that in the non-neuraxial blockade group; the systemic opioid varied in seven trials, ${ }^{28} 344384120186192$ the use of inhalational anaesthetic varied in two trials, ${ }^{7140}$ the type of inhalational anaesthetic varied in two trials, ${ }^{148} 165$ the induction drug varied in one trial, ${ }^{191}$ and more than one aspect varied in 10 trials. $^{42} 76808197151161168169189$ For three (2\%) trials details of the general anaesthesia method were unknown.

Among the 56 trials for which follow up data were available, the mean duration of follow up was about 62 days. Only 13 trials provided follow up data beyond 30 days postoperatively. No events were recorded in 80 trials involving 2941 participants, which were mostly designed to assess the physiological, biochemical, and endocrine effects of neuraxial blockade. The mean follow up in the first 30 days these trials was 11 days, compared with 21 days in trials in which events were observed.

\section{Overall mortality}

A total of 247 deaths within 30 days of randomisation were recorded in 35 trials. Overall mortality was about one third less in the neuraxial blockade group (odds ratio $0.70,95 \%$ confidence interval 0.54 to 0.90 , $\mathrm{P}=0.006$; fig 1) with no clear difference between different surgical groups (fig 2). A specific diagnosis was available for 162 of the deaths. Of these, $73(45 \%)$ were due to pulmonary embolism, cardiac events, or stroke, $50(31 \%)$ were due to infective causes, and $39(24 \%)$ were due to other causes. The observed improvement in survival was due to trends towards reductions in deaths from pulmonary embolism, cardiac events, or stroke $(0.73,0.45$ to 1.16$)$, deaths from infection $(0.68$, 0.39 to 1.21$)$, deaths from other causes $(0.84,0.44$ to $1.61)$, and deaths from unknown causes $(0.64,0.41$ to 1.01). There was about one fewer death per 100 patients in the 30 days after randomisation in the neuraxial blockade group $(103 / 4871 \quad(2.1 \%)$ versus $144 / 4688(3.1 \%))$. Only six intraoperative deaths were recorded, one of which was in the neuraxial blockade group $(0.28,0.06$ to 1.45$)$. Ten studies, with a total of 1371 patients, recorded 130 deaths between 30 days and six months. All but two of these studies were on orthopaedic patients. Overall, there was no clear effect of neuraxial blockade on deaths during this period $(0.89,0.61$ to 1.28$)$. 
Table 1 Characteristics of included studies

\begin{tabular}{|c|c|c|c|c|c|c|c|c|c|c|c|c|c|c|}
\hline \multirow{2}{*}{$\begin{array}{l}\text { First author and } \\
\text { year of } \\
\text { publication }\end{array}$} & \multicolumn{2}{|c|}{$\begin{array}{l}\text { No of patients } \\
\text { randomised }\end{array}$} & \multicolumn{2}{|c|}{$\begin{array}{l}\text { No without } \\
\text { mortality data }\end{array}$} & \multicolumn{2}{|c|}{$\begin{array}{l}\text { Mean age } \\
\text { (years) }\end{array}$} & \multicolumn{2}{|c|}{ No of men } & \multicolumn{2}{|c|}{$\begin{array}{l}\text { No with ASA } \\
\text { status I or II }\end{array}$} & \multirow[b]{2}{*}{ Type of NB* } & \multirow{2}{*}{$\begin{array}{c}\text { General } \\
\text { anaesthesia } \\
\text { used in NB } \\
\text { group }\end{array}$} & \multirow{2}{*}{$\begin{array}{c}\text { NB } \\
\text { continued } \\
\text { after } \\
\text { surgery }\end{array}$} & \multirow{2}{*}{$\begin{array}{l}\text { Mean length } \\
\text { of follow up } \\
\text { (days) }\end{array}$} \\
\hline & NB & No NB & NB & No NB & NB & No NB & NB & No NB & NB & No NB & & & & \\
\hline General & & & & & & & & & & & & & & \\
\hline Asoh 1983 & 10 & 10 & - & - & 59 & 57 & 7 & 7 & - & - & Thoracic & No & Yes & - \\
\hline Bottiglieri 1992 & 10 & 10 & - & - & - & - & - & - & - & - & Thoracic & Yes & Yes & - \\
\hline Cuschieri 1985 & 25 & 50 & 0 & 0 & 51 & 52 & 5 & 11 & - & - & Thoracic & Yes & Yes & 4 \\
\hline De Kock 1993 & 20 & 20 & - & - & 34 & 37 & 13 & 13 & - & - & Lumbar & Yes & Yes & - \\
\hline Godfrey 1981 & 34 & 34 & 0 & 0 & - & - & 34 & 34 & - & - & Lumbar & No & No & 30 \\
\hline Goertz 1993 & 24 & 12 & 0 & 0 & 52 & 44 & - & - & - & - & Thoracic & Yes & Yes & - \\
\hline Hendolin 1987 & 60 & 40 & 0 & 0 & 56 & 55 & 10 & 8 & - & - & Thoracic & Yes & Yes & 7 \\
\hline Hjortso 1985 & 50 & 50 & 6 & 0 & 66 & 69 & 23 & 21 & 42 & 47 & Thoracic & Yes & Yes & 10 \\
\hline Jayr 1988 & 75 & 75 & 1 & 3 & 60 & 59 & 44 & 37 & - & - & Thoracic & Yes & Yes & 5 \\
\hline Jayr 1993 & 82 & 81 & 4 & 6 & 58 & 56 & 43 & 55 & - & - & Thoracic & Yes & Yes & 17 \\
\hline Jensen 1980 & 6 & 6 & 0 & 0 & 51 & 54 & 6 & 6 & 6 & 6 & Lumbar & No & No & - \\
\hline Mellbring 1983 & 25 & 25 & 0 & 0 & 62 & 61 & 13 & 19 & - & - & Thoracic & Yes & Yes & - \\
\hline Moiniche 1992 & 15 & 16 & 0 & 0 & 54 & 45 & 3 & 4 & 15 & 16 & Thoracic & Yes & Yes & 2 \\
\hline Naesh 1994 & 7 & 7 & - & - & - & - & 7 & 7 & 7 & 7 & Lumbar & No & No & - \\
\hline Naesh 1994 & 8 & 8 & - & - & 52 & 47 & 0 & 0 & 8 & 8 & Lumbar & Yes & No & 4 \\
\hline Ogata 1985 & 10 & 10 & 0 & 0 & 55 & 50 & - & - & - & - & Thoracic & Yes & - & - \\
\hline Rutberg 1984 & 16 & 8 & 0 & 0 & 43 & 43 & 0 & 0 & 16 & 8 & Thoracic & Yes & Yes & 3 \\
\hline Ryan 1992 & 57 & 43 & 12 & 8 & 65 & 66 & - & - & - & - & Thoracic & Yes & Yes & 14 \\
\hline Scheinin 1982 & 30 & 10 & 0 & 0 & - & - & 13 & 5 & - & - & Thoracic & Yes & Yes & 2 \\
\hline Seeling 1990 & 124 & 123 & 26 & 7 & 61 & 58 & 93 & 88 & 58 & 63 & Thoracic & Yes & Yes & - \\
\hline Seeling 1991 & 223 & 116 & 38 & 9 & 60 & 58 & 134 & 79 & 91 & 60 & $\begin{array}{c}\text { Thoracic or } \\
\text { lumbar }\end{array}$ & Yes & Yes & - \\
\hline Traynor 1982 & 9 & 9 & - & - & 52 & 49 & 2 & 1 & 9 & 9 & Thoracic & Yes & No & - \\
\hline Tverskoy 1990 & 12 & 24 & - & - & 54 & 56 & 12 & 24 & 12 & 24 & Spinal & No & No & - \\
\hline Watters 1993 & 12 & 8 & - & - & 64 & 65 & 4 & 8 & - & - & Lumbar & Yes & Yes & 2 \\
\hline Worsley 1988 & 47 & 51 & 0 & 0 & 53 & 53 & - & - & - & - & Spinal & Yes & No & 19 \\
\hline Yeager 1987 & 28 & 27 & 0 & 2 & 71 & 72 & - & - & - & - & Thoracic & Yes & Yes & - \\
\hline Abboud 1985 & 32 & 20 & 0 & 0 & 28 & 29 & 0 & 0 & - & - & Spinal or lumbar & No & No & - \\
\hline Blunnie 1983 & 15 & 30 & - & - & 42 & 41 & 0 & 0 & 15 & 30 & Spinal & Yes & No & - \\
\hline Brandt 1978 & 6 & 6 & - & - & 36 & 40 & 0 & 0 & 6 & 6 & Lumbar & No & Yes & - \\
\hline Buckley 1982 & 6 & 7 & 0 & 0 & 38 & 39 & 0 & 0 & 6 & 7 & Lumbar & Yes & Yes & - \\
\hline $\begin{array}{c}\text { Christensen } \\
1982\end{array}$ & 12 & 24 & - & - & - & - & 0 & 0 & - & - & Lumbar & No & - & - \\
\hline Dick 1992 & 23 & 24 & - & - & 27 & 28 & 0 & 0 & 23 & 24 & Lumbar & No & No & - \\
\hline Halevy 1978 & 14 & 18 & - & - & - & - & 0 & 0 & 14 & 18 & Lumbar & No & No & - \\
\hline Holdcroft 1979 & 15 & 37 & 0 & 0 & 32 & 30 & 0 & 0 & 32 & 30 & Lumbar & Yes & No & - \\
\hline Jensen 1977 & 9 & 9 & - & - & 42 & 45 & 0 & 0 & 9 & 9 & Lumbar & Yes & No & - \\
\hline Jordanov 1985 & 27 & 20 & 0 & 0 & 29 & 31 & 0 & 0 & 22 & 20 & $\begin{array}{c}\text { Thoracic or } \\
\text { lumbar }\end{array}$ & No & Yes & - \\
\hline Kocknover 1982 & 45 & 45 & - & - & - & - & 0 & 0 & - & - & Lumbar & Yes & No & - \\
\hline Lehtinen 1987 & 11 & 13 & 0 & 0 & 29 & 38 & 0 & 0 & 11 & 13 & Lumbar & No & No & - \\
\hline Licker 1994 & 10 & 9 & 1 & 0 & 51 & 47 & 0 & 0 & 10 & 9 & Lumbar & Yes & Yes & 5 \\
\hline Murakami 1987 & 20 & 17 & 0 & 0 & 41 & 43 & 0 & 0 & - & - & Lumbar & No & - & - \\
\hline Rem 1980 & 6 & 6 & - & - & 38 & 39 & 0 & 0 & 6 & 6 & Lumbar & No & No & - \\
\hline Simpson 1982 & 6 & 30 & 0 & 0 & 44 & 44 & 0 & 0 & 6 & 30 & Lumbar & Yes & No & 8 \\
\hline Wallace 1995 & 54 & 26 & 0 & 0 & - & - & 0 & 0 & - & - & Spinal or lumbar & No & No & - \\
\hline Wattwil 1987 & 20 & 20 & - & - & - & - & 0 & 0 & - & - & Lumbar & Yes & Yes & - \\
\hline Wessen 1994 & 10 & 10 & 0 & 0 & 43 & 45 & 0 & 0 & 10 & 10 & Lumbar & Yes & Yes & 2 \\
\hline Subtotal & 341 & 371 & 1 & 0 & 35 & 36 & 0 & 0 & 170 & 212 & & & & 6 \\
\hline Orthopaedic & & & & & & & & & & & & & & \\
\hline Berggren 1987 & 28 & 29 & - & - & 78 & 77 & 4 & 7 & - & - & Lumbar & No & No & - \\
\hline Bigler 1985 & 20 & 20 & 0 & 0 & 80 & 78 & 2 & 5 & 17 & 16 & Spinal & No & No & 90 \\
\hline Bonnet 1982 & 5 & 14 & - & - & 60 & 58 & 1 & 5 & - & - & Lumbar & No & No & - \\
\hline Brendahl 1991 & 15 & 15 & 0 & 2 & 80 & 79 & 0 & 0 & 15 & 15 & Spinal & No & No & - \\
\hline Brown 1994 & 10 & 10 & 0 & 0 & 75 & 79 & 5 & 5 & 6 & 7 & Spinal & No & No & 2 \\
\hline Chin 1982 & 21 & 21 & 0 & 0 & 73 & 74 & 10 & 9 & 21 & 21 & Lumbar & Yes & No & 6 \\
\hline $\begin{array}{c}\text { Christensen } \\
1986 \\
\end{array}$ & 6 & 8 & 0 & 0 & 65 & 65 & - & - & - & - & Lumbar & No & Yes & - \\
\hline
\end{tabular}


Table 1 contd

\begin{tabular}{|c|c|c|c|c|c|c|c|c|c|c|c|c|c|c|}
\hline \multirow{2}{*}{$\begin{array}{l}\text { First author and } \\
\text { year of } \\
\text { publication }\end{array}$} & \multicolumn{2}{|c|}{$\begin{array}{l}\text { No of patients } \\
\text { randomised }\end{array}$} & \multicolumn{2}{|c|}{$\begin{array}{c}\text { No without } \\
\text { mortality data }\end{array}$} & \multicolumn{2}{|c|}{$\begin{array}{l}\text { Mean age } \\
\text { (years) }\end{array}$} & \multicolumn{2}{|c|}{ No of men } & \multicolumn{2}{|c|}{$\begin{array}{l}\text { No with ASA } \\
\text { status I or II }\end{array}$} & \multirow[b]{2}{*}{ Type of NB* } & \multirow{2}{*}{$\begin{array}{c}\text { General } \\
\text { anaesthesia } \\
\text { used in NB } \\
\text { group }\end{array}$} & \multirow{2}{*}{$\begin{array}{c}\text { NB } \\
\text { continued } \\
\text { after } \\
\text { surgery }\end{array}$} & \multirow{2}{*}{$\begin{array}{l}\text { Mean length } \\
\text { of follow up } \\
\text { (days) }\end{array}$} \\
\hline & NB & No NB & NB & No NB & NB & No NB & NB & No NB & NB & No NB & & & & \\
\hline Davis 1981 & 64 & 68 & 0 & 0 & 81 & 78 & 11 & 9 & 23 & 24 & Spinal & No & No & 28 \\
\hline Davis 1987 & 265 & 284 & - & - & - & - & - & - & - & - & Spinal & No & No & 28 \\
\hline Davis 1989‡ & 69 & 71 & 0 & 0 & 68 & 67 & 31 & 31 & - & - & Spinal & No & No & 14 \\
\hline Donadoni 1988 & 51 & 29 & 0 & 0 & 62 & 67 & - & - & 0 & 0 & Lumbar & Yes & Yes & 2 \\
\hline Fredin 1986 & 30 & 30 & 2 & 2 & 67 & 66 & 11 & 8 & - & - & Lumbar & No & Yes & - \\
\hline Hole 1980 & 29 & 31 & 0 & 0 & 70 & 72 & 10 & 11 & 27 & 29 & Lumbar & No & No & 300 \\
\hline Hole 1983 & 13 & 14 & - & - & - & - & - & - & - & - & Lumbar & No & Yes & - \\
\hline Hole 1984 & 10 & 10 & 0 & 0 & 62 & 64 & 4 & 1 & 10 & 9 & Lumbar & No & Yes & 24 \\
\hline Hole 1984 & 10 & 10 & 0 & 0 & 67 & 70 & 3 & 3 & 8 & 8 & Lumbar & No & Yes & - \\
\hline Jakobsen 1986 & 15 & 15 & 0 & 0 & 72 & 72 & - & - & - & - & Lumbar & No & Yes & - \\
\hline Jones 1990 & 76 & 75 & 2 & 3 & - & - & 20 & 19 & - & - & Spinal & No & No & 90 \\
\hline Keith 1977 & 10 & 17 & - & - & 61 & 64 & 5 & 3 & - & - & Lumbar & No & No & - \\
\hline Mann 1983 & 30 & 30 & 0 & 0 & 71 & 70 & 18 & 16 & 10 & 12 & Spinal & No & No & 180 \\
\hline Maurette 1988 & 18 & 15 & 0 & 0 & 81 & 85 & - & - & 18 & 15 & Spinal & No & No & - \\
\hline McKenzie 1984 & 75 & 75 & 6 & 2 & 75 & 74 & 8 & 17 & 38 & 34 & Spinal & No & No & 365 \\
\hline McLaren 1982 & 56 & 60 & - & - & - & - & - & - & - & - & Spinal & No & No & 30 \\
\hline Modig 1980 & 15 & 15 & 0 & 0 & 67 & 65 & 8 & 7 & 15 & 15 & Lumbar & No & Yes & 30 \\
\hline Modig 1986 & 50 & 50 & 2 & 4 & 65 & 66 & 27 & 22 & 48 & 46 & Lumbar & No & Yes & 30 \\
\hline Modig 1987 & 14 & 24 & 0 & 0 & 67 & 67 & 5 & 13 & 14 & 24 & Lumbar & No & Yes & 30 \\
\hline Nielsen 1989 & 10 & 20 & - & - & 34 & 38 & 5 & 10 & 5 & 10 & Lumbar & No & No & - \\
\hline Nielsen 1990 & 25 & 39 & - & - & - & - & - & - & - & - & Spinal & No & - & - \\
\hline Pedersen 1986 & 15 & 15 & 0 & 0 & 72 & 72 & 9 & 10 & - & - & Lumbar & No & Yes & - \\
\hline Poll 1988 & 24 & 26 & 0 & 0 & - & - & - & - & - & - & Lumbar & Yes & Yes & - \\
\hline Racle 1986 & 35 & 35 & 0 & 0 & 82 & 82 & 0 & 0 & - & - & Spinal & No & No & 30 \\
\hline Riis 1983 & 20 & 10 & - & - & 70 & 70 & - & - & - & - & Lumbar & Yes & Yes & 90 \\
\hline Seitz 1985 & 10 & 10 & 0 & 0 & - & - & 10 & 10 & - & - & Lumbar & No & No & - \\
\hline Sharrock 1992 & 11 & 10 & - & - & - & - & - & - & - & - & Lumbar & No & Yes & - \\
\hline Tulla 1992 & 10 & 10 & 0 & 0 & 61 & 59 & 5 & 5 & 8 & 10 & Spinal & No & No & 4 \\
\hline Valentin 1986§ & 281 & 297 & - & - & 79 & 79 & 58 & 59 & 192 & 182 & Spinal & No & No & - \\
\hline White 1980 & 20 & 40 & 0 & 4 & 78 & 79 & 1 & 7 & 8 & 18 & Spinal & Yes & No & 28 \\
\hline $\begin{array}{l}\text { Williams-Russo } \\
1995\end{array}$ & 134 & 128 & 0 & 0 & 69 & 69 & 40 & 38 & - & - & Lumbar & No & Yes & 180 \\
\hline Subtotal & 1768 & 1849 & 12 & 21 & 71 & 71 & 382 & 410 & 559 & 572 & & & & 84 \\
\hline Urology & & & & & & & & & & & & & & \\
\hline Asbjorn $1989 \S$ & 20 & 20 & 0 & 0 & 69 & 69 & 20 & 20 & 20 & 20 & Lumbar & No & Yes & 21 \\
\hline Chung 1987 & 20 & 24 & - & - & 73 & 72 & 9 & 12 & - & - & Spinal & No & No & - \\
\hline Chung 1989 & 22 & 22 & - & - & 72 & 72 & 22 & 22 & 13 & 14 & Spinal & No & No & - \\
\hline Dobson 1994 & 11 & 11 & - & - & 77 & 72 & 11 & 11 & 11 & 11 & Spinal & No & No & - \\
\hline Edwards 1995 & 52 & 48 & - & - & - & - & 52 & 48 & - & - & Spinal & No & No & - \\
\hline Foate 1985 & 8 & 9 & - & - & 69 & 69 & 8 & 9 & - & - & Spinal & No & No & - \\
\hline Frank 1994 & 15 & 15 & 0 & 0 & 61 & 62 & 15 & 15 & 15 & 15 & Lumbar & No & Yes & 0 \\
\hline Hendolin 1981 & 17 & 21 & - & - & 71 & 67 & 17 & 21 & - & - & Lumbar & No & Yes & - \\
\hline Henny 1986 & 10 & 10 & - & - & 62 & 62 & 10 & 10 & - & - & Lumbar & No & Yes & - \\
\hline Jenkins 1983 & 7 & 8 & - & - & 68 & 68 & 7 & 8 & - & - & Lumbar & No & No & - \\
\hline McGowan 1980 & 50 & 100 & 0 & 0 & - & - & 50 & 100 & - & - & Spinal & No & No & 7 \\
\hline Melsen 1987 & 45 & 59 & 0 & 0 & 68 & 64 & 36 & 53 & 45 & 59 & Lumbar & No & No & - \\
\hline Nielsen 1987 & 25 & 20 & 7 & 2 & - & - & - & - & - & - & Lumbar & No & No & - \\
\hline Poikolainen 1983 & 17 & 21 & - & - & - & - & - & - & - & - & Lumbar & No & No & - \\
\hline Rickford 1988 & 53 & 25 & - & - & 45 & 46 & 31 & 13 & 31 & 13 & Spinal or lumbar & No & No & - \\
\hline Shir 1994 & 69 & 34 & - & - & - & - & - & - & - & - & Lumbar & Yes & Yes & - \\
\hline $\begin{array}{l}\text { Stjernstrom } \\
1985\end{array}$ & 15 & 10 & - & - & 71 & 66 & 15 & 10 & 15 & 10 & Lumbar & No & No & - \\
\hline Whelan 1982 & 7 & 8 & - & - & 64 & 66 & 7 & 8 & - & - & Spinal & No & No & - \\
\hline Subtotal & 463 & 465 & 7 & 2 & 64 & 65 & 310 & 360 & 150 & 142 & & & & 10 \\
\hline Vascular & & & & & & & & & & & & & & \\
\hline Baron 1991 & 87 & 86 & 6 & 0 & 61 & 62 & 70 & 81 & - & - & Thoracic & Yes & Yes & - \\
\hline Bode 1996 & 285 & 138 & 0 & 0 & 68 & 68 & 40 & 81 & 0 & 0 & Spinal or lumbar & Yes & Yes & - \\
\hline Bonnet 1989 & 10 & 11 & - & - & 63 & 64 & 9 & 11 & - & - & Thoracic & Yes & No & - \\
\hline
\end{tabular}


Table 1 contd

\begin{tabular}{|c|c|c|c|c|c|c|c|c|c|c|c|c|c|c|}
\hline \multirow{2}{*}{$\begin{array}{l}\text { First author and } \\
\text { year of } \\
\text { publication }\end{array}$} & \multicolumn{2}{|c|}{$\begin{array}{l}\text { No of patients } \\
\text { randomised }\end{array}$} & \multicolumn{2}{|c|}{$\begin{array}{l}\text { No without } \\
\text { mortality data }\end{array}$} & \multicolumn{2}{|c|}{$\begin{array}{l}\text { Mean age } \\
\text { (years) }\end{array}$} & \multicolumn{2}{|c|}{ No of men } & \multicolumn{2}{|c|}{$\begin{array}{l}\text { No with ASA } \\
\text { status I or II }\end{array}$} & \multirow[b]{2}{*}{ Type of NB* } & \multirow{2}{*}{$\begin{array}{c}\text { General } \\
\text { anaesthesia } \\
\text { used in NB } \\
\text { group }\end{array}$} & \multirow{2}{*}{$\begin{array}{c}\text { NB } \\
\text { continued } \\
\text { after } \\
\text { surgery }\end{array}$} & \multirow{2}{*}{$\begin{array}{l}\text { Mean length } \\
\text { of follow up } \\
\text { (days) }\end{array}$} \\
\hline & NB & No NB & NB & No NB & NB & No NB & NB & No NB & NB & No NB & & & & \\
\hline Cook 1986 & 50 & 51 & 0 & 0 & 66 & 67 & 35 & 36 & 19 & 20 & Spinal & No & No & 365 \\
\hline Damask 1990 & 9 & 10 & - & - & 71 & 64 & 6 & 8 & - & - & Lumbar & No & No & - \\
\hline Davies 1993 & 25 & 25 & 0 & 0 & 65 & 67 & 23 & 21 & - & - & Thoracic & Yes & Yes & 7 \\
\hline Garnett 1996 & 55 & 56 & 7 & 5 & 68 & 69 & 37 & 43 & 0 & 0 & Lumbar & Yes & Yes & - \\
\hline Gold 1994 & 12 & 12 & 0 & 0 & 73 & 71 & 9 & 9 & 0 & 0 & Lumbar & Yes & Yes & 8 \\
\hline Haljamae 1988 & 27 & 28 & - & - & 65 & 60 & 19 & 20 & - & - & Lumbar & Yes & No & - \\
\hline Homann 1984 & 19 & 38 & - & - & 46 & 41 & 8 & 13 & - & - & Lumbar & No & No & - \\
\hline Houweling 1993 & 40 & 20 & 0 & 0 & 65 & 65 & 32 & 15 & - & - & Spinal or lumbar & Yes & Yes & 10 \\
\hline Kossman 1982 & 9 & 10 & - & - & - & - & - & - & - & - & Thoracic & Yes & Yes & - \\
\hline Reinhart 1989 & 35 & 70 & - & - & 63 & 61 & 25 & 52 & 13 & 28 & Thoracic & Yes & Yes & 5 \\
\hline Rosseel 1985 & 9 & 9 & - & - & 67 & 65 & 8 & 8 & 0 & 0 & Thoracic & Yes & No & - \\
\hline Seeling 1985 & 25 & 26 & 1 & 0 & 62 & 62 & 22 & 24 & 11 & 14 & Thoracic & Yes & Yes & - \\
\hline Stenseth 1994 & 20 & 10 & 0 & 0 & 55 & 54 & 20 & 10 & 0 & 0 & Thoracic & Yes & Yes & 6 \\
\hline Truman 1991 & 40 & 40 & 0 & 0 & 70 & 66 & 17 & 15 & 0 & 0 & Thoracic & Yes & Yes & 20 \\
\hline Wust 1980 & 23 & 45 & - & - & 58 & 60 & 20 & 41 & 12 & 18 & Thoracic & Yes & No & - \\
\hline Subtotal & 905 & 806 & 15 & 5 & 65 & 63 & 486 & 570 & 61 & 86 & & & & 94 \\
\hline \multicolumn{15}{|l|}{ Other surgery } \\
\hline Brichon 1994 & 46 & 33 & - & - & 53 & 45 & - & - & - & - & Thoracic & Yes & Yes & - \\
\hline Bromage 1971 & 22 & 22 & - & - & 43 & 48 & - & - & - & - & Thoracic & Yes & Yes & - \\
\hline Ghoneim 1988 & 52 & 53 & - & - & 62 & 60 & 35 & 35 & - & - & Spinal or lumbar & No & No & 90 \\
\hline Hasenbos 1985 & 83 & 80 & 0 & 0 & 42 & 36 & 65 & 60 & 21 & 14 & Thoracic & Yes & Yes & 4 \\
\hline Jia 1985 & 67 & 31 & - & - & - & - & - & - & - & - & - & - & - & - \\
\hline Merhav 1993 & 16 & 15 & - & - & 40 & 46 & 14 & 11 & - & - & Spinal & No & No & - \\
\hline Ogata 1988 & 8 & 13 & - & - & - & - & - & - & - & - & Thoracic & Yes & - & - \\
\hline Ravin 1971 & 10 & 10 & - & - & 71 & 70 & - & - & - & - & Spinal & No & No & - \\
\hline Slinger 1995 & 15 & 15 & - & - & 65 & 62 & 12 & 11 & - & - & Lumbar & Yes & Yes & 3 \\
\hline Zwarts 1989 & 10 & 10 & - & - & 38 & 50 & 5 & 8 & - & - & Thoracic & Yes & Yes & - \\
\hline Subtotal & 329 & 282 & 0 & 0 & 50 & 48 & 131 & 125 & 21 & 14 & & & & 34 \\
\hline
\end{tabular}

${ }^{*} \mathrm{NB}=$ neuraxial blockade.

†In excluded patients only.

$\ddagger 11$ patients were entered twice into this study.

$\S=$ The total number randomised was not available.Those presented are the numbers included in the study after exclusions and losses to follow up.

Mortality results by type of anaesthesia

Seven trials (with 826 participants) directly randomised patients to spinal or epidural anaesthesia. ${ }^{25} 3277104153181$ Only 13 deaths occurred in these trials, four in the spinal group. However, an indirect comparison between trials of spinal and epidural anaesthesia showed no clear difference between their effects on total mortality $(0.68,0.49$ to 0.95 for spinal anaesthesia and $0.68,0.43$ to 1.07 for epidural anaesthesia, P for homogeneity =1.0; fig 2). Mortality was reduced overall whether neuraxial blockade was continued postoperatively $(0.68,0.43$ to 1.08$)$ or not $(0.70,0.51$ to 0.97$)$. The effect on total mortality was not clearly lower in trials in which neuraxial blockade was combined with general anaesthesia $(0.87,0.53$ to 1.41$)$ than in trials in which neuraxial blockade was used alone $(0.64,0.47$ to 0.87 ; $\mathrm{P}$ for homogeneity $=0.3$; fig 2). However, the confidence intervals were wide for the trials that used general anaesthesia. Forty four (18\%) deaths occurred in the 22 trials in which the neuraxial blockade group had a different general anaesthesia to that used in the group not allocated neuraxial blockade. The overall effect in this group of trials $(0.92$, 0.49 to 1.71) was not clearly different ( $\mathrm{P}$ for homogeneity $=0.3)$ from that in other trials $(0.66,0.49$ to 0.88 ).

Table 2 Summary of vascular events and bleeding

Vascular events

\begin{tabular}{|c|c|c|c|}
\hline \multicolumn{4}{|c|}{ Bleeding } \\
\hline \multicolumn{2}{|c|}{$\begin{array}{l}\text { Perioperative } \\
\text { transfusion } \\
\text { requiring }>2 \text { units } \\
\text { red cells }\end{array}$} & \multicolumn{2}{|c|}{$\begin{array}{l}\text { Postoperative } \\
\text { bleed requiring } \\
\text { transfusion }\end{array}$} \\
\hline NB & No NB & NB & No NB \\
\hline 61 & 80 & 0 & 0 \\
\hline 81 & 125 & 21 & 57 \\
\hline 12 & 32 & 0 & 0 \\
\hline 38 & 41 & 9 & 11 \\
\hline 1 & 2 & 1 & 1 \\
\hline 193 & 280 & 31 & 69 \\
\hline
\end{tabular}

$\mathrm{NB}=$ neuraxial blockade. 
Table 3 Summary of infection, other events, and mortality

\begin{tabular}{|c|c|c|c|c|c|c|c|c|c|c|c|c|c|c|c|c|}
\hline \multirow{2}{*}{ Group } & \multicolumn{6}{|c|}{ Infection } & \multicolumn{4}{|c|}{ Other events } & \multicolumn{6}{|c|}{ Mortality } \\
\hline & \multicolumn{2}{|c|}{ Wound infection } & \multicolumn{2}{|c|}{ Pneumonia } & \multicolumn{2}{|c|}{$\begin{array}{l}\text { Death from other } \\
\text { infective cause }\end{array}$} & \multicolumn{2}{|c|}{$\begin{array}{l}\text { Respiratory } \\
\text { depression }\end{array}$} & \multicolumn{2}{|c|}{ Renal failure } & \multicolumn{2}{|c|}{ Total mortality } & \multicolumn{2}{|c|}{$\begin{array}{c}\text { No of } \\
\text { intraoperative } \\
\text { deaths }\end{array}$} & \multicolumn{2}{|c|}{$\begin{array}{l}\text { No of deaths } \\
\text { between } 30 \text { days } \\
\text { and } 6 \text { months }\end{array}$} \\
\hline General & 17 & 13 & 64 & 99 & 2 & 1 & 16 & 14 & 1 & 3 & 18 & 18 & 0 & 0 & 0 & 1 \\
\hline Orthopaedics & 9 & 14 & 63 & 84 & 0 & 1 & 0 & 1 & 10 & 14 & 58 & 89 & 0 & 1 & 57 & 66 \\
\hline Urology & 0 & 0 & 0 & 0 & 0 & 0 & 0 & 1 & 0 & 0 & 4 & 6 & 0 & 0 & 0 & 0 \\
\hline Other & 1 & 2 & 0 & 0 & 0 & 0 & 0 & 0 & 0 & 0 & 0 & 0 & 0 & 0 & 0 & 0 \\
\hline Total & 29 & 33 & 149 & 238 & 2 & 10 & 26 & 38 & 18 & 32 & 103 & 144 & 1 & 5 & 60 & 70 \\
\hline
\end{tabular}

$\mathrm{NB}=$ neuraxial blockade.

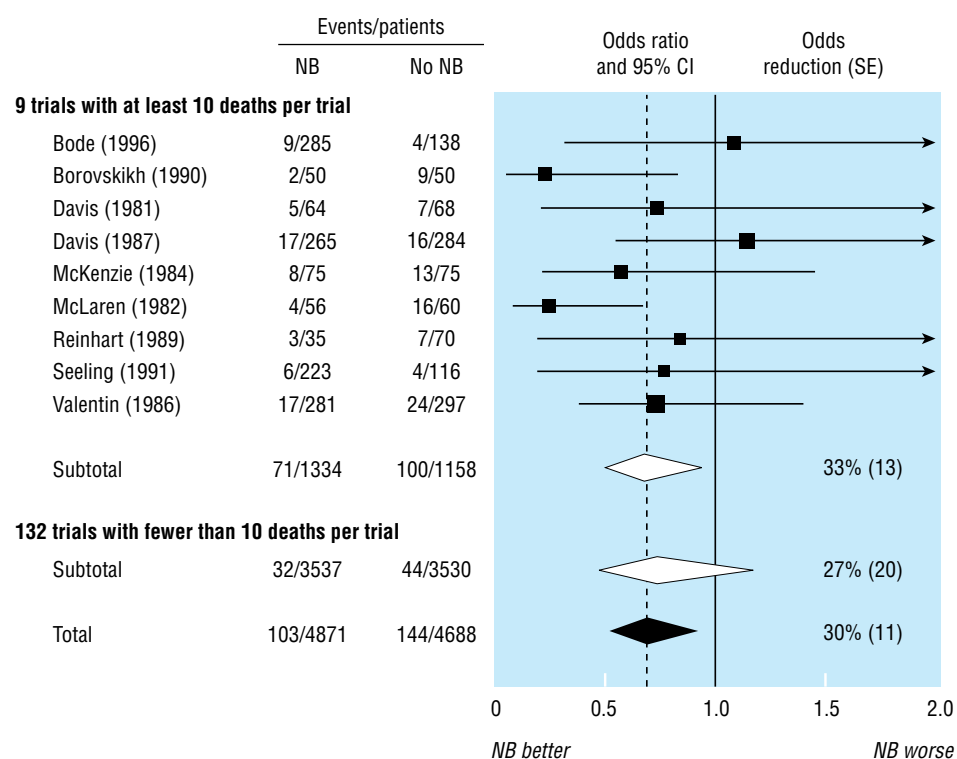

Fig 1 Effect of neuraxial blockade (NB) on postoperative mortality within 30 days of randomisation. Diamonds denote $95 \%$ confidence intervals for odds ratios of combined trial results. The vertical dashed line represents the overall pooled result. Size of shaded boxes is proportional to number of events. The overall event rates after adjusting for uneven randomisation ${ }^{193}$ were $113 / 5811(1.9 \%)$ versus $158 / 5667(2.8 \%) \cdot \chi^{2}$ test for heterogeneity between individual trials $\mathrm{P}=0.5$

Venous thromboembolism, cardiac events, and stroke

A total of 365 deep vein thromboses were reported from 18 trials. Neuraxial blockade reduced the risk of deep vein thrombosis by almost half $(0.56,0.43$ to 0.72 ; fig 3). Since more than $80 \%$ of deep vein thromboses were recorded in orthopaedic trials, there was limited power to detect differences between surgical groups. In nine trials all patients were screened for deep vein thromboses by fibrinogen scanning, ${ }^{59} 87129$ venography, ${ }^{74114132187}$ or a combination of methods. ${ }^{62}{ }^{94}$ Proportional reductions in deep vein thromboses were similar in the trials with screening $(0.56,0.42$ to 0.75$)$ compared with other trials $(0.54,0.30$ to 0.96$)$. Therefore, absolute differences were much greater in the trials with screening (121/463 (26\%) for neuraxial blockade versus 178/467 (38\%) for no neuroaxial blockade) than in other trials $(24 / 4408(0.5 \%)$ versus $42 / 4221(1.0 \%))$. Outcome assessments were known to be blinded in only two trials, and deep vein thromboses were also reduced in these studies $(0.46,0.21$ to 0.99). ${ }^{66}$ A total of 96 pulmonary emboli were reported from 23 trials, 21 (22\%) of which were fatal.
Overall, there were about half as many pulmonary emboli in patients allocated to neuraxial blockade $(0.45,0.29$ to 0.69 ; fig 3$)$.

A total of 104 myocardial infarctions were reported in 30 trials. Overall, there were about one third fewer myocardial infarctions in patients allocated to neuraxial blockade, but the confidence intervals were compatible with both no effect and a halving in risk $(0.67,0.45$ to 1.00 ; fig 3). Only 42 strokes were reported from eight trials, and the confidence intervals were very wide for this outcome $(0.85,0.46$ to 1.57 ; fig 3$)$.

\section{Bleeding}

In total, 473 patients from 16 trials required transfusion of two or more units of blood and 100 patients from 12 trials had a postoperative bleed requiring a transfusion. The requirement for a transfusion of two or more units of blood was reduced by about half in patients allocated neuraxial blockade $(0.50,0.39$ to 0.66 ; fig 3$)$. A similar proportional reduction was found for postoperative bleeds requiring a transfusion $(0.45,0.29$ to 0.70 ; fig 3$)$. There was no clear difference in the proportional effects on either outcome across surgical groups.

\section{Postoperative infection}

In total, 62 wound infections were reported from 14 trials. There were fewer wound infections in those allocated to neuraxial blockade, although the confidence intervals were wide $(0.79,0.47$ to 1.33 ; fig 3$)$. Three hundred and eighty seven cases of pneumonia were recorded in 28 trials, of which $38(10 \%)$ were fatal. The risk of developing pneumonia was less in patients randomised to neuraxial blockade $(0.61,0.48$ to 0.76 ; fig $3)$. There was no clear difference in the proportional effects with the use of concomitant general anaesthesia (neuraxial blockade versus general anaesthesia: 0.63, 0.46 to 0.87 ; neuraxial blockade plus general anaesthesia versus general anaesthesia: $0.59,0.42$ to 0.81 ). However, there was some evidence ( $\mathrm{P}$ for homogeneity $=0.05)$ that the proportional reduction in pneumonia was greater after thoracic epidural anaesthesia $(0.48,0.35$ to 0.67$)$ than after lumbar epidural or spinal anaesthesia $(0.76,0.55$ to 1.04$)$. Twelve deaths due to an infective cause other than pneumonia were recorded in six trials, of which two occurred in patients allocated to neuraxial blockade (0.33, 0.10 to 1.07 ; fig 3$)$.

\section{Other postoperative events}

A total of 64 cases of respiratory depression were reported from eight trials. The odds of respiratory depression were reduced by $59 \%$ in patients allocated 
to neuraxial blockade $(0.41,0.23$ to 0.73 ; fig 3$)$. The effect was present in trials with and without concomitant general anaesthesia (neuraxial blockade alone versus general anaesthesia $0.37,0.11$ to 1.21 ; neuraxial blockade plus general anaesthesia versus general anaesthesia $0.43,0.22$ to 0.81 ). Fifty cases of renal failure were recorded in 10 trials. Although the risk of renal failure was reduced in patients randomised to neuraxial blockade, the confidence intervals were wide and compatible with both no effect and a two thirds reduction $(0.57,0.32$ to 1.00 ; fig 3$)$.

\section{Sensitivity analyses}

We conducted several analyses to assess whether the effects on total mortality were dependent on trials with methodological problems or affected by the type of anaesthesia. However, all these tests lacked power to detect moderate sized differences.

An overall reduction in mortality was still evident after we excluded studies for which the total number of patients originally randomised was not available $(0.68, \quad 0.51 \text { to } 0.91)^{26180}$; original authors could not be contacted $(0.69, \quad 0.53$ to

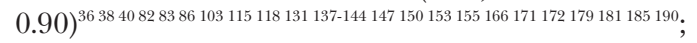
more than $5 \%$ of all patients were lost to follow up or excluded after randomisation $(0.69,0.51$ to 0.91) 3143238576271747594108113114120129130140159164165171173181187 ; or more than $5 \%$ of the neuraxial blockade group were excluded after randomisation $(0.68,0.51$ to 0.91). ${ }^{28} 32577594113120129130140159164165171173$ The reduction in mortality was also evident after exclusion of two trials that were stopped before scheduled completion $(0.70$, 0.53 to 0.91$)$ and exclusion of unpublished data $(0.67$, 0.51 to 0.88$).{ }^{28} 4694109130165$ Finally, there was no clear evidence of publication bias from tests for trend across groups defined by trial size.

\section{Discussion}

Our overview shows improved survival in patients randomised to neuraxial blockade. Additionally, we found reductions in risk of venous thromboembolism, myocardial infarction, bleeding complications, pneumonia, respiratory depression, and renal failure. There was no clear evidence that these effects, in proportional terms, differed by the type of surgical group or the type of neuraxial blockade, although there was limited power to assess subgroup effects reliably. Furthermore, there was no evidence of "catch up" mortality in the neuraxial blockade group between 30 days and 6 months.

The benefits seen for neuraxial blockade may be conferred by multifactorial mechanisms, including altered coagulation, increased blood flow, improved ability to breathe free of pain, and reduction in surgical stress responses. ${ }^{2}$ In particular, major surgery induces a "stress response" that is substantially altered by neuraxial blockade but not by general anaesthesia. ${ }^{2}$ This observation, together with the subgroup comparisons shown here, suggests that these benefits are principally due to the use of neuraxial blockade rather than avoidance of general anaesthesia. Thus the key issue seems to be whether neuraxial blockade is used or not, and the way in which this is achieved is less relevant.

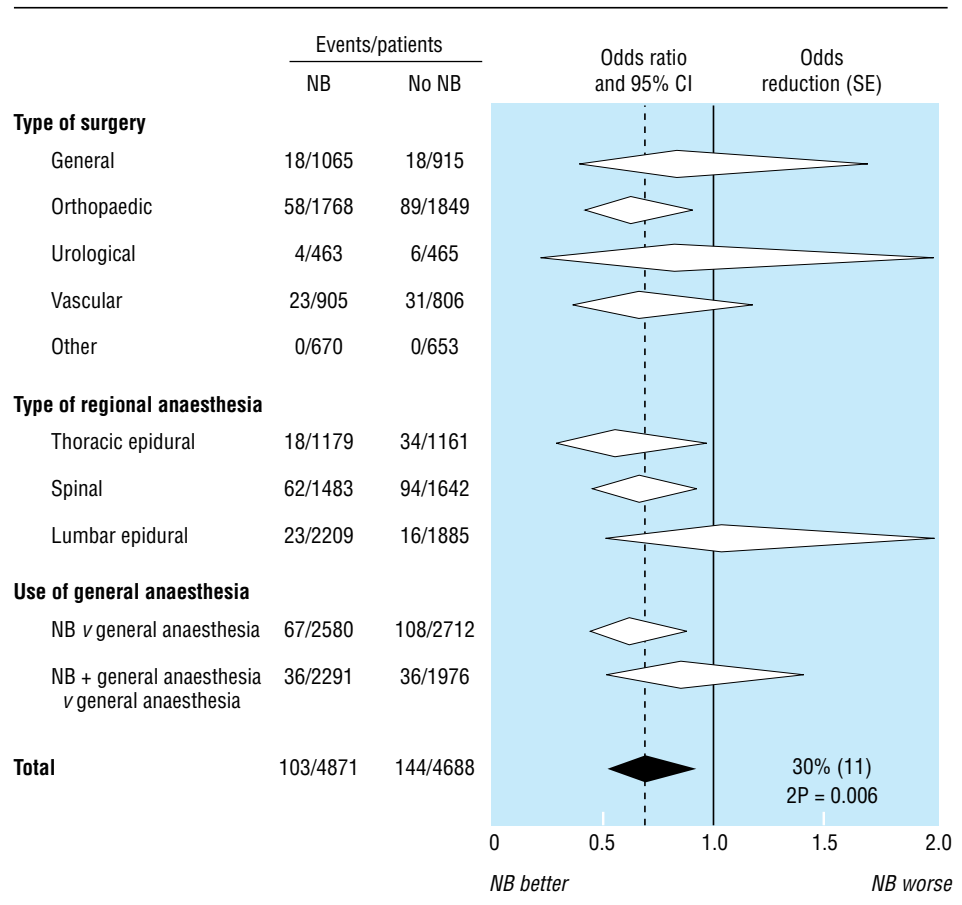

Fig 2 Effect of neuraxial blockade (NB) on postoperative mortality, by surgical group, type of neuraxial blockade, and use of general anaesthesia. Obstetrics and gynaecology trials are included with other surgery. One trial with unknown details of anaesthesia was grouped with lumbar epidural and neuraxial blockade plus general anaesthesia versus general anaesthesia comparisons. Diamonds denote $95 \%$ confidence intervals for odds ratios of combined trial results. The vertical dashed line represents the overall pooled result. Size of shaded boxes is proportional to number of events. $\chi^{2}$ test for heterogeneity between different surgical groups, $\mathrm{P}=0.9$

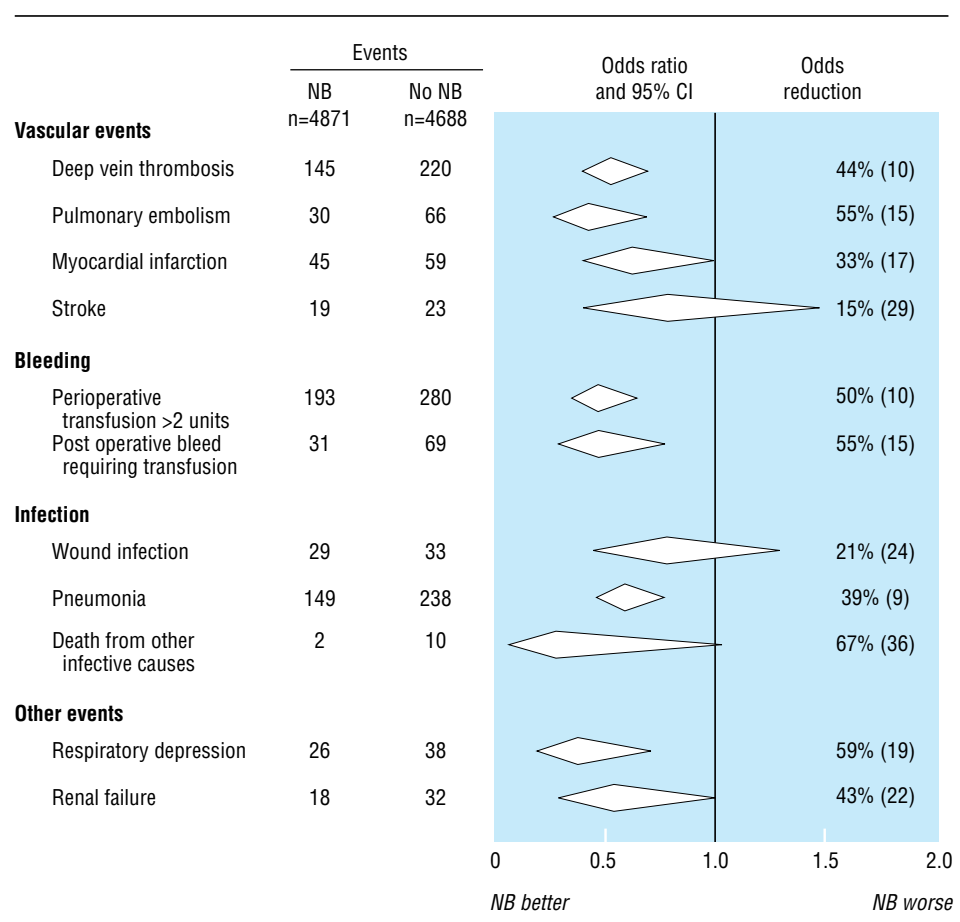

Fig 3 Effects of neuraxial blockade (NB) on postoperative complications. Diamonds denote $95 \%$ confidence intervals for odds ratios of combined trial results. The vertical dashed line represents the overall pooled result. Size of shaded boxes is proportional to number of events 


\section{Validity of findings}

It is unlikely that bias could explain much of the reduction in mortality. We included all randomised trials, irrespective of their initial aims or reported findings. Most trials were not designed to assess major events, but it is unlikely that we missed many deaths or major non-fatal events because we contacted the authors of trials involving $87 \%$ of patients and few patients had no outcome data. However, incidence will have been underestimated for non-fatal events that often go undiagnosed, such as deep vein thrombosis. This finding will not bias relative risk estimates ${ }^{6}$ unless information is selectively available from trials with extreme results. For deep vein thrombosis, at least, the proportional effect of neuraxial blockade in trials designed to assess this outcome was similar to that in other trials. With regard to other potential biases, lack of blinding may have caused some selective misdiagnosis of non-fatal events, but analyses did not indicate publication bias and the overall reduction in mortality was not dependent on inclusion of trials with unconfirmed data or trials for which intention to treat analyses were not possible. Lastly, even though these data represent most of the randomised evidence potentially available, the confidence intervals were wide for many outcomes and relatively little information was available about cause of death.

If the proportional effects of neuraxial blockade are consistent in different patient populations, neuraxial blockade would be expected to result in about one fewer postoperative death and several fewer major complications for every 100 patients at similar risk to those in the studies. However, even though such benefits would be widely regarded as clinically important, the largest individual trial to date ${ }^{180}$ did not have the power to reliably detect effects of this size. Lack of statistical power may therefore be the principal reason why previous individual trials, editorials, ${ }^{194}$ and meta-analyses of trials in hip fracture patients ${ }^{195} 196$ have concluded that neuraxial blockade had no important effect on mortality.

\section{Implications}

Our overview indicates that neuraxial blockade reduces major postoperative complications in a wide range of patients. However, uncertainty about the net benefits of neuraxial blockade is likely to remain among some clinicians and for some patient groups. For example, opinion is divided about whether neuraxial blockade is indicated or contraindicated in patients at risk of cardiac complications, ${ }^{197}$ and it is unclear whether the differences that we observed reflect the benefits of neuraxial blockade alone or are partly due to the avoidance of the adverse effects of general anaesthesia. Such uncertainties provide the rationale for large randomised trials, such as the ongoing multicentre Australian study of epidural anaesthesia and analgesia in major surgery. ${ }^{198}$ However, since serious complications associated with neuraxial blockade, such as spinal haematoma, are very rare ${ }^{199-201}$ and more common side effects, such as headache or urinary retention, are not life threatening, our data support recent trends towards increased use of neuraxial blockade. Furthermore, although we focused on intraoperative anaesthetic techniques, postoperative neuraxial blockade has been shown to have
What is already known on this topic

Neuraxial blockade with epidural or spinal anaesthesia reduces the incidence of deep vein thrombosis and one month mortality in hip fracture patients

Insufficient evidence exists for other postoperative outcomes in this surgical group

\section{What this study adds}

Mortality was reduced by one third in patients allocated neuraxial blockade

Reductions in mortality did not differ by surgical group, type of blockade, or in trials in which neuraxial blockade was combined with general anaesthesia

Neuraxial blockade also reduced the risk of deep vein thrombosis, pulmonary embolism, transfusion requirements, pneumonia, respiratory depression, myocardial infarction, and renal failure

additional benefits, at least for pulmonary complications. ${ }^{202}$ Overall, therefore our data should result in more widespread use of spinal or epidural anaesthesia.

We thank all trialists who confirmed data and provided extra information for this overview: T K Abboud, A R Aitkenhead, T Asoh, J F Baron, A Bayer, D Berggren, P Berthelsen, D Bigler, P K Bithal, W P Blunnie, R Bode, F Bonnet, N A Borovskikh, M R Brandt, S Bredbacka, M J Breslow, F P Buckley, K S Channer, S P Chin, R Christopherson, F Chung, E Couderc, R J Cuschieri, J B Dahl, F M Davies, M J Davies, M Davis, M De Kock, J Devulder, W Dick, N D Edwards, S M Frank, R L Garnett, S Gelman, S P Gerrish, M M Ghoneim, M S Gold, A Gottlieb, E Hakansson, M Hasenbos, H Hendolin, S W Henneberg, A Holdcroft, A Hole, R Hosoda, P L Houweling, A O Hughes, C Jayr, J Jenkins, N Jia, R D M Jones, L N Jorgensen, J Kanto, H Kehlet, A Lehtinen, M Licker, R A M Mann, P Maurette, S McGowan, P J McKenzie, A D McLaren, G Mellbring, N Melsen, I Milsom, J Modig, S Moiniche, I Murat, J M Murray, J A Odoom, M S J Pathy, J Pedersen, J S Poll, A V Pollock, J P Racle, S Raja, K Reinhart, H Renck, B Rosberg, B A Rosenfeld, H Rutberg, P Ryan, B Scheinin, W Seeling, N Sharrock, I Smilov, T Stathopoulou, R Stenseth, V I Strashnov, J Takala, J Takeda, M V Tseshinsky, H Tsuji, K J Tuman, N Valentin, J M Watters, L G Welborn, A Wessen, I W C White, C Wiessman, $\mathrm{P}$ Williams-Russo, $\mathrm{M}$ P Yeager, and $\mathrm{O} \mathrm{N}$ Zabrodin. We thank Iain Chalmers, Rory Collins, Mike Davis, Konrad Jamrozik, John McCall, Tom Pedersen, John Rigg, and Charles Warlow for their helpful comments and Gary Whitlock, Xin-Hua Zhang, Philippa Day, and Valentine Kravtsov for help with translating papers.

Contributors: AR had the original idea for this study. All authors contributed actively to the protocol. NW and AR performed all searching for trials and AM, SS, and GS abstracted the data. NW and TC carried out all data analysis. AR, NW, AM, TC, and SS wrote the first draft of the paper and HK, AvZ, DS, MF, and SM made revisions. AR will act as guarantor for the paper.

Funding: Health Research Council of New Zealand and Astra Pain, New Zealand. NW undertook this research during the tenure of a training fellowship from the Health Research Council of New Zealand. AR is a senior research fellow of the National Heart Foundation of New Zealand.

Competing interests: HK has received fees for consulting and speaking at meetings from AstraZeneca.

1 Cousins M, Bridenbaugh P, eds. Neural blockade in clinical anesthesia and management of pain. 2nd ed. Philadelphia:J B Lippincott, 1988.

2 Kehlet H. Modification of responses to surgery by neural blockade: clinical implications. In: Cousins M, Bridenbaugh P, eds. Neural blockade in 
clinical anesthesia and management of pain. 2nd ed. Philadelphia: J B Lippincott, 1988:145-88.

3 Jones M, Piggott S, Vaughan R, Bayer A, Newcombe R, Twining T, et al Cognitive and functional competence after anaesthesia in patients aged over 60: controlled trial of general and regional anaesthesia for elective hip or knee replacement. BMJ 1990;300:1683-7.

4 Dickersin K, Larson K. Establishing and maintaining an international register of RCTs. Oxford: Cochrane Collaboration, 1995.

5 Greenland S. Quality scores are useless and potentially misleading. Am Epidemiol 1994;140:300-1.

6 Rodgers A, MacMahon S. Systematic underestimation of treatment effects as a result of diagnostic test inaccuracy: implications for the interpretation and design of thromboprophylaxis trials. Thromb Haemost 1995;73:167-71.

7 Yusuf S, Peto R, Lewis J, Collins R, Sleight P. Beta blockade during and after myocardial infarction: an overview of the randomized trials. Prog Cardiovasc Dis 1985;27:335-71.

8 Bredbacka S, Blomback M, Hagnevik K, Irestedt L, Raabe N. Per-and postoperative changes in coagulation and fibrinolytic variables during abdominal hysterectomy under epidural or general anaesthesia. Acta Anaesthesiol Scand 1986:30:204-10.

9 Gregoretti S. Comparison of water, electrolyte and nitrogen balance in the postoperative period after epidural or general anesthesia: a randomised study of patients undergoing hysterectomy. Minerza Anestesiol 1985;51:87-91.

10 Jia N, Guo H, San Y, Liu L. Comparison of changes in plasma catecholamines between general anesthesia and general anesthesia plus epidural block. Acta Acad Med Sinicae 1991;13:112-4

1 Konishi M, Yamada M, Yamada T, Noguchi J, Takeda J. The effects of halothane and epidural anesthesia on the gastric intramural $\mathrm{pH}$ and the $\mathrm{pH}$ of the gastric juice. Masui 1989;38:329-33.

12 Mitchell D, Friedman RJ, Baker JD, Cooke JE, Darcy MD, Miller MC. Prevention of thromboembolic disease following total knee arthroplasty. Epidural versus general anesthesia. Clin Orthop 1991;269:109-12.

13 Modig J, Malmberg P, Karlstrom G. Effect of epidural versus genera anaesthesia on calf blood flow. Acta Anaesthesiol Scand 1980;24:305-9.

14 ModigJ, Hjelmstedt A, Sahlstedt B, Maripuu E. Comparative influences of epidural and general anaesthesia on deep venous thrombosis and pulmonary embolism after total hip replacement. Acta Chir Scand 1981;147:125-30.

15 Modig J, Borg T, Karlstrom G, Maripuu E, Sahlstedt B. Thromboembolism after total hip replacement: role of epidural and general anesthesia Anesth Analg 1983;62:174-80.

16 Perhoniemi V, Linko K. Hemodynamics of the legs and clinical symptoms following regional blocks for transurethral surgery. Eur Urol 1986;12:244-8.

17 Wickstrom I, Holmberg I, Stefansson T. Survival of female geriatric patients after hip fracture surgery. A comparison of 5 anesthetic methods. Acta Anaesthesiol Scand 1982;26:607-14.

8 Asoh T, Tsuji H. Post-operative complications of gastrectomy in patient with gastric cancer. (Unpublished.)

19 Rosberg B, Fredin H, Gustafson C. Anaesthetic techniques and surgica blood loss in total hip arthroplasty. Acta Anaesthesiol Scand 1982;26:18993.

20 Shirasaka C, Tsuji H, Asoh T, Takeuchi Y. Role of splanchnic nerves in endocrine and metabolic response to abdominal surgery. Br J Surg 1986;73:142-5

21 Tsuji H, Asoh Y, Takeuchi Y, Shirasaka C. Attenuation of adrenocortical response to upper abdominal surgery with epidural blockade. Br J Surg 1983;70:122-4.

22 Tsuji H, Shirasaka C, Asoh T, Takeuchi Y. Influences of splanchnic nerve blockade on endocrine-metabolic responses to upper abdominal surgery. BrJ Surg 1983;70:437-9.

23 Uchida I, Asoh T, Shirasaka C, Tsuji H. Effect of epidural analgesia on postoperative insulin resistance as evaluated by insulin clamp technique. Br J Surg 1988;75:557-62.

24 Planes A, Vochelle N, Fagola M, Feret J, Bellaud M. Prevention of deep vein thrombosis after total hip replacement: the effect of low molecular weight heparin with spinal and general anaesthesia. J Bone Joint Surg Br 1991;73B:418-22.

25 Abboud TK, Nagappala S, Murakawa K, David S, Haroutunian S, Zakarian M, et al. Comparison of the effects of general and regional anesthesia for cesarean section on neonatal nuerologic and adaptive capacity scores. Anesth Analg 1985;64:996-1000.

26 Asbjorn J, Jakobsen B, Pilegaard H, Blom L, Ostergaard A, Brandt M. Mental function in elderly men after surgery during epidural analgesia. Acta Anaesthesiol Scand 1989;33:369-73

27 Asoh T, Tsuji H, Shirasaka C, Takeuchi Y. Effect of epidural analgesia on metabolic response to major upper abdominal surgery. Acta Anaesthesio Scand 1983;27:233-7.

28 Baron J, Bertrand M, Barre E, Godet G, Mundler O, Coriat P, et al. Combined epidural and general anesthesia versus general anesthesia for abdominal aortic surgery. Anesthesiology 1991;75:611-8.

29 Berggren D, Gustafson Y, Eriksson B, Bucht G, Hansson LI, Reiz S, et al Postoperative confusion after anesthesia in elderly patients with femoral neck fractures. Anesth Analg 1987;66:497-504.

30 Bigler D, Adelhoj B, Petring O, Pederson N, Busch P, Kalhke P. Menta function and morbidity after acute hip surgery during spinal and general anaesthesia. Anaesthesia 1985;40:672-6.

31 Blunnie W, Mcllroy A, Merrett J, Dundee J. Cardiovascular and biochemical evidence of stress during major surgery associated with different techniques of anaesthesia. BrJ Anaesth 1983;55:611-7.

32 Bode R, Lewis K, Zarich S, Pierce E, Roberts M, Kowalchuk G, et al. Cardiac outcome after peripheral vascular surgery: comparison of general and regional anesthesia. Anesthesiology 1996;84:3-13.
33 Bonnet F, Harari A, Thibonnier M, Viars P. Suppression of antidiuretic hormone hypersecretion during surgery by extradural anaesthesia. $\mathrm{Br}$ Anaesth 1982;54:29-35.

34 Bonnet F, Touboul C, Picard A, Vodinh J, Becquemin J. Neuroleptanesthesia versus thoracic epidural anesthesia for abdominal aortic surgery. Ann Vasc Surg 1989;3:214-9.

35 Borovskikh N, Lebedev L, Strashkov V, Vinogradov A. Comparative evaluation of the effectiveness of epidural anesthesia with spontaneous respiration and general anesthesia in aorto-femoral bifurcation shunt Vestn Khir Im II Grek 1990;145:95-8.

36 Bottiglieri T, Petros A, Smith D, Ronzoni G, Carli F. The effect of extradural bupivacaine on CSF monoamine metabolites in surgical patients. Reg Anesth 1992;17(Suppl):95.

37 Brandt M, Fernandes A, Mordhorst R, Kehlet H. Epidural analgesia improves postoperative nitrogen balance. BMJ 1978;i:1106-8

38 Bredahl C, Hindsolm KB, Frandsen PC. Changes in body heat during hip fracture surgery: a comparison of spinal analgesia and general anaesthesia. Acta Anaesthesiol Scand 1991;35:548-52.

39 Brichon P, Pison C, Chaffanjon P, Fayot P, Buchberger M, Neron L, et al. Comparison of epidural analgesia and cryoanalgesia in thoracic surgery. Eur J Cardiothorac Surg 1994;8:482-6.

40 Bromage P, Shibata H, Willoughby R. Influence of prolonged epidural blockade on blood sugar and cortisol responses to operations upon the upper part of the abdomen and the thorax. Surg Gynecol Obstel 1971;132:1051-6

41 Brown A, Visram A, Jones R, Irwins M, Bacon-Shone J. Preoperative and postoperative oxygen saturation in the elderly following spinal or general anaesthesia-an audit of current practice. Anaesth Intensive Care 1994:22:150-4.

42 Buckley F, Kehlet H, Brown N, Scott D. Postoperative glucose tolerance during extradural analgesia. Br J Anaesth 1982;54:325-31.

43 Chin S, Abou Madi M, Eurin B, Witvoet J, Montagne J. Blood loss in total hip replacement: extradural v. phenoperidine analgesia. Br J Anaesth $1982 ; 54: 491-5$

44 Christensen P, Brandt M, Rem J, Kehlet H. Influence of extradura morphine on the adrenocortical and hyperglycaemic response to surgery. Br J Anaesth 1982;54:23-6.

45 Christensen T, Waaben J, Lindeburg T, Vesterberg K, Vinnars E, Kehlet H. Effect of epidural analgesia on muscle amino acid pattern after surgery. Acta Chir Scand 1986;152:407-11.

46 Christopherson R, Beattie C, Frank S, Norris E, Meinert C, Gottlieb S, et al. Perioperative morbidity in patients randomized to epidural or general anesthesia for lower extremity vascular surgery. Anesthesiology 1993;79:422-34

47 Breslow M, Parker S, Frank S, Norris E, Yates H, Raff H, et al. Determinants of catecholamine and cortisol responses to lower extremity revascularization. Anesthesiology 1993;79:1202-9.

48 Frank S, Beattie C, Christopherson R, Norris E, Rock P, Parker S, et al. Epidural versus general anesthesia, ambient operating room temperature, and patient age as predictors of inadvertent hypothermia. Anesthesiology 1992;77:252-7.

49 Rosenfeld B, Beattie C, Christopherson R, Norris E, Frank S, Breslow M, et al. The effects of different anesthetic regimes on fibrinolysis and the development of postoperative arterial thrombosis. Anesthesiology 1993;79:435-43.

50 Chung F, Meier R, Lautenschlager E, Carmichael F, Chung A. General or spinal anesthesia: which is better in the elderly? Anesthesiology 1987:67:422-7.

51 Chung F, Chung A, Meier R, Lautenshlaeger E, Seyone C. Comparison of perioperative mental function after general anaesthesia and spinal anaesthesia with intravenous sedation. Can J Anaesth 1989;36:382-7.

52 Cook P, Davies M, Cronin K, Moran P. A prospective randomised tria comparing spinal anaesthesia using hyperbaric cinchocaine with general anaesthesia for lower limb vascular surgery. Anaesth Intensive Care 1986; $14: 373-80$

53 Couderc E, Mauge F, Duvaldestin P, Desmonts J. Resultats comparatifs de l'anesthesie generale et peridurale chez le grand vieillard dans la chirurgie de la hanche. Anesth Anal Reanim 1977;34:987-98.

54 Cuschieri R, Morran C, Howie J, McArdle C. Postoperative pain and pulmonary complications: comparison of three analgesic regimens. BrJ Surg 1985;72:495-8

55 Dahl J, Schultz P, Anker-Moller E, Christensen E, Staunstrup H, Carlsson P. Spinal anaesthesia in young patients using a 29-gauge needle: technical considerations and an evaluation of postoperative complaints compared with general anaesthesia. BrJ Anaesth 1990;64:178-82.

56 Damask MC, Weissman C, Todd G. General versus epidural anesthesia for femoral-popliteal bypass surgery. J Clin Anesth 1990;2:71-5.

57 Darling J, Murray J, Hainsworth A, Trinick T. The effect of isoflurane or spinal anesthesia on indocyanine green disappearance rate in the elderly. Anesth Analg 1994:78:706-9.

58 Davies M, Silbert B, Mooney P, Dysart R, Meads A. Combined epidural and general anaesthesia versus general anaesthesia for abdominal aortic surgery: a prospective randomised trial. Anaesth Intensive Car 1993;21:790-4

59 Davis F, Laurenson V. Spinal anaesthesia or general anaesthesia for emergency hip surgery in elderly patients. Anaesth Intensive Care 1981;9:352-8.

60 Davis F, Quince M, Laurenson V. Deep vein thrombosis and anaesthetic technique in emergency hip surgery. BMJ 1980;281:1528-9.

61 Davis F, Woolner D, Frampton C, Wilkinson A, Grant A, Harrison R, et al. Prospective, multi-centre trial of mortality following general or spinal anaesthesia for hip fracture surgery in the elderly. $\mathrm{Br} J$ Anaesth $1987 ; 59: 1080-8$

62 Davis F, Laurenson V, Gillespie W, Wells J, Foate J, Newman E. Deep vein thrombosis after total hip replacement: a comparison between spinal and epidural anaesthesia. J Bone Joint Surg Br 1989;71B:181-5. 
63 Davis F, McDermott E, Hickton C, Wells E, Heaton D, Laurenson V, et al. Influence of spinal and general anaesthesia on haemostasis during total hip arthroplasty. Br J Anaesth 1987;59:561-71.

64 Davis F, Laurenson V, Lewis J, Wells J, Gillespie W. Metabolic response to total hip arthroplasty under hypobaric subarachnoid or general anaesthesia. Br J Anaesth 1987;59:725-9.

65 Davis F, Larenson V, Gillespie W, Foate J, Seagar A. Leg blood flow during total hip replacement under spinal or general anaesthesia. Anaesth Intensive Care 1989;17:136-43.

66 De Kock M, Crochet B, Morimont C, Scholtes J. Intravenous or epidural clonidine for intra- and postoperative analgesia. Anesthesiology 1993;79:525-31.

67 Dick W, Traub E, Kraus H, Tollner U, Burghard R, Muck J. General anaesthesia versus epidural anaesthesia for primary caesarean section-a comparative study. Eur J Anaesthesiol 1992;9:15-21.

68 Dobson P, Caldicott L, Gerrish S, Cole J, Channer K. Changes in haemodynamic variables during transurethral resection of the prostate: comparison of general and spinal anaesthesia. Br J Anaesth 1994;72:26771 .

69 Donadoni R, Baele G, Rolly G, Devulder M. Influence of epidural anesthesia on coagulation factors in patients undergoing total hip replacement. Reg Anesth 1988;13:55.

70 Edwards N, Callaghan L, White T, Reilly C. Perioperative myocardial ischaemia in patients undergoing transurethral surgery: a pilot study comparing general with spinal anaesthesia. Br J Anaesth 1995;74:368-72.

71 Foate J, Horton H, Davis F. Lower limb blood flow during transurethral resection of the prostate under spinal or general anaesthesia. Anaesth Intensive Care 1985;13:383-6.

72 Frank S, Shir Y, Raja S, Fleisher L, Beattie C. Core hypothermia and skin surface temperature gradients. Anesthesiology 1994;80:502-7.

73 Fleisher L, Frank S, Shir Y, Estafanous M, Kelly S, Raja S. Cardiac sympathovagal balance and peripheral sympathetic vasoconstriction: epidural versus general anesthesia. Anesth Analg 1994;79:165-71.

74 Fredin H, Rosberg B. Anaesthetic techniques and thromboembolism in total hip arthroplasty. Eur J Anaesthesiol 1986;3:273-81.

75 Garnett R, MacIntyre A, Lindsay P, Barber G, Cole C, Hajjar G, et al. Perioperative ischaemia in aortic surgery: combined epidural/general anaesthesia and epidural analgesia vs general anaesthesia and iv analgesia. Can J Anaesth 1996;43:769-77.

76 Gelman S, Laws H, Potzick J, Strong S, Smith L, Erdemir H. Thoracic epidural vs balanced anesthesia in morbid obesity: an intraoperative and postoperative hemodynamic study. Anesth Analg 1980;59:902-8.

77 Ghoneim M, Hinrichs JV, O'Hara MW, Mehta MP, Pathak D, Kumar V, et al. Comparison of psychologic and cognitive functions after general or regional anesthesia. Anesthesiology 1988;69:507-15.

78 Godfrey P, Greenan J, Ranasinghe D, Shabestary S, Pollock A. Ventilatory capacity after three methods of anaesthesia for inguinal hernia repair: a randomized controlled trial. Br J Surg 1981;68:587-9.

79 Goertz A, Seeling W, Heinrich H, Lindner K, Schirmer U. Influence of high thoracic epidural anesthesia on left ventricular contractility assessed using the end-systolic pressure-length relationship. Acta Anaesthesiol Scand 1993;37:38-44.

80 Gold M, DeCrosta D, Rizzuto C, Ben-Harari R, Ramanathan S. The effect of lumbar epidural and general anesthesia on plasma catecholamines and hemodynamics during abdominal aortic aneurysm repair. Anesth Analg 1994;78:225-30

81 Gottlieb A, McCoy C, Augereau P, Beven E. Hemodynamics of aortic clamping: a comparison between general and lumbar epidural anesthesia. Reg Anesth 1988;13:69.

82 Halevy S, Liu-Barnett M, Ross P, Roginsky M. Serum thyroid hormones changes in patients undergoing caesarean section under general or regional anaesthesia. Br J Anaesth 1978;50:1053-7.

83 Haljamae H, Frid I, Holm J, Akerstrom G. Epidural vs general anaesthesia and leg blood flow in patients with occlusive atherosclerotic disease. EurJ Vasc Surg 1988;2:395-400.

84 Hasenbos M, van Egmond J, Gielen M, Crul J. Post-operative analgesia by epidural versus intramuscular nicomorphine after thoracotomy. Part 1. Acta Anaesthesiol Scand 1985;29:572-6.

85 Hasenbos M, van Egmond J, Gielen M, Crul J. Post-operative analgesia by epidural versus intramuscular nicomorphine after thoracotomy. Part 2. Acta Anaesthesiol Scand 1985;29:577-82.

86 Hedenstierna G, Lofstrom J. Effect of anaesthesia on respiratory function after major lower extremity surgery. Acta Anaesthesiol Scand 1985;29:5560.

87 Hendolin H, Mattila M, Poikolainen E. The effect of lumbar epidural analgesia on the development of deep vein thrombosis of the legs after open prostatectomy. Acta Chir Scand 1981;147:425-9.

88 Hendolin H, Lansimies E. Skin and central temperatures during continuous epidural analgesia and general anaesthesia in patients subjected to open prostatectomy. Ann Clin Research 1982;14:181-6.

89 Hendolin H, Alhava E. Effect of epidural versus general anaesthesia on peroperative blood loss during retropubic prostatectomy. Int Urol Nephrol 1982:14:399-405.

90 Hendolin H, Lahtinen J, Lansimies E, Tuppurainen T. The effect of thoracic epidural analgesia on postoperative stress and morbidity. Ann Chir Gynaecol 1987;76:234-40.

91 Hendolin H, Tuppurainen T, Lahtinen J. Thoracic epidural analgesia and deep vein thrombosis in cholecystectomized patients. Acta Chir Scand 1982:48:405-9.

92 Hendolin H, Lahtinen J, Lansimies E, Tuppurainen T, Partanen K. The effect of thoracic epidural analgesia on respiratory function after cholecystectomy. Acta Anaesthesiol Scand 1987;31:645-51.

93 Henny C, Oddoom J, Ten Cate H, Ten Cate J, Oosterhoff R, Dabhoiwala $\mathrm{N}$, et al. Effects of extradural bupivacaine on the haemostatic system. $\mathrm{Br} J$ Anaesth 1986;58:301-5.
94 Hjortso N, Neumann P, Frosig F, Anderson T, Lindhard A, Rogon E, et al. A controlled study on the effect of epidural analgesia with local anaesthetics and morphine on morbidity after abdominal surgery. Acta Anaesthesiol Scand 1985;29:790-6.

95 Hjortso N, Andersen T, Frosig F, Neumann P, Rogon E, Kehlet H. Failure of epidural analgesia to modify postoperative depression of delayed hypersensitivity. Acta Anaesthesiol Scand 1984;28:128-31.

96 Hjortso N, Christensen N, Andersen T, Kehlet H. Effects of the extradural administration of local anaesthetic agents and morphine on the urinary excretion of cortisol, catecholamines and nitrogen following abdomial surgery. Br J Anaesth 1985;57:400-6.

97 Holdcroft A, Hall G, Cooper G. Redistribution of body heat during anaesthesia. Anaesthesia 1979:34:758-64.

98 Hole A, Terjesen T, Breivik H. Epidural versus general anaesthesia for total hip arthroplasty in elderly patients. Acta Anaesthesiol Scand 1980;24:279-87.

99 Hole A, Unsgaard G. The effect of epidural and general anaesthesia on lymphocyte functions during and after major orthopaedic surgery. Acta Anaesthesiol Scand 1983;27:135-41.

100 Hole A, Unsgaard G, Breivik H. Monocyte functions are depressed during and after surgery under general anaesthesia but not under epidura anaesthesia. Acta Anaesthesiol Scand 1982;26:301-7.

101 Hole A. Per- and postoperative monocyte and lymphocyte functions: effects of sera from patients operated under general or epidural anaeshesia. Acta Anaesthesiol Scand 1984:84:287-91.

102 Hole A, Bakke O. T-lymphocytes and the subpopulations of T-helper and T-suppressor cells measured by monoclonal antibodies (T11,T and T8) in relation to surgery under epidural and general anaesthesia. Acta Anaesthesiol Scand 1984;28:296-300.

103 Homann B, Blumenberg D, Lerner H. The influence of anaesthesia on plasma levels of factor XIII. Anaesthesist 1984;33:145-8.

104 Houweling P, Ionescu T, Leguit P, Van Der Tweel I, Smalhout B. Comparison of the cardiovascular effects of intravenous, epidural and intrathecal sufentanil analgesia as a supplement to general anaesthesia for abdominal aortic aneurysm surgery. Eur J Anesthesiol 1993;10:40311.

105 Jakobsen BW, Pederson J, Egeberg BB. Postoperative lymphocytopenia and leucocytosis after epidural and general anaesthesia. Acta Anaesthesiol Scand 1986;30:668-71.

106 Jayr C, Mollie A, Bourgain J, Truffa Bachi J, Treich G. Postoperative pulmonary complications after abdominal surgery: epidural compared with parenteral morphine analgesia. Reg Anesth 1988;13:6.

107 Jayr C, Mollie A, Bourgain J, Alarcon J, Masselot J, Lasser P, et al. Postoperative pulmonary complications: general anesthesia with postoperative parenteral morphine compared with epidural analgesia. Surgery 1988; 104:57-63.

108 Jayr C, Thomas H, Rey A, Farhat F, Lasser P, Bourgain J. Postoperative pulmonary complications: epidural analgesia using bupivacaine and opioids versus parenteral opioids. Anesthesiology 1993;78:666-76.

109 Jenkins J, Fox J, Sharwood Smith G. Changes in body heat during transvesical prostatectomy. Anaesthesia 1983;38:748-53.

110 Jensen B, Berthelsen P, Brochner-Mortensen J. Glomerular filtration rate during halothane anaesthesia and epidural analgesia in combination with halothane anaesthesia. Acta Anaesthesiol Scand 1977;21:395-9.

111 Jensen CH, Berthelsen P, Kuhl C, Kehlet H. Effect of epidural analgesia on glucose tolerance during surgery. Acta Anaesthesiol Scand 1980;24:472-4

112 Jia N, Luo L, Zhao J, Yan W, Liu B, Zhang Y, et al. Influence of epidural and general anesthesia on human plasma cAMP. Chin Med J 1985;65:30-3.

113 Jordanov K, Smilov I, Ninio A, Mincheva-Saeva M. A comparative study on epidural and general anaesthesia in elective caesarian section. Akush Ginekol (Sofiia) 1985;24:31-40.

114 Jorgensen L, Rasmussen L, Nielsen P, Leffers A, Albrecht Beste E. Antithrombotic efficacy of continuous extradural analgesia after knee replacement. Br J Anaesth 1991;66:8-12.

115 Kausalya R, Jacob R. Efficacy of low-dose epidural anaesthesia in surgery of the anal canal-a randomised controlled trial. Anaesth Intensive Care 1994;22:161-4.

116 Keith I. Anaesthesia and blood loss in total hip replacement. Anaesthesia 1977;32:444-50.

117 Kokhnover S, Manevich L, Molchanova G. Comparative study of prolonged peridural anesthesia and combined general anesthesia in operative gynecology. Akush Ginekol (Sofiia) 1982;6:48-52.

118 Kossman B, Volk E, Spilker E, Maier V, Fehm H. Influence of thoracic epidural analgesia on glucose, cortisol, insulin and glucagon responses to surgery. Reg Anesth 1982;7:107-9.

119 Lehtinen AM, Laatikainen T, Koskimies AI, Hovorka J. Modifying effects of epidural analgesia or general anesthesia on the stress hormone response to laparoscopy for in vitro fertilization. J In Vitro Fert Embryo Transf 1987;4:23-9.

120 Licker M, Suter P, Krauer F, Rifat N. Metabolic response to lower abdominal surgery: analgesia by epidural blockade compared with intravenous opiate infusion. Eur J Anaesthesiol 1994;11:193-9.

121 Mann R, Bisset W. Anaesthesia for lower limb amputation: a comparison of spinal analgesia and general analgesia in the elderly. Anaesthesia 1983;38:1185-91

122 Maurette P, Castagnera L, Vivier C, Erny P. Psychological assessment in the elderly after general and spinal anaesthesia. Ann Fr Anesth Reanim 1988;7:305-8.

123 McGowan S, Smith G. Anaesthesia for transurethral prostatectomy: a comparison of spinal intradural analgesia with two methods of general anaesthesia. Anaesthesia 1980;35:847-53. 
124 McKenzie P, Wishart H, Smith G. Long-term outcome after repair of fractured neck of femur. Comparison of subarachnoid and general anaesthesia. Br J Anaesth 1984;56:581-4.

125 McKenzie P, Wishart H, Dewar K, Gray I, Smith G. Comparison of the effects of spinal anaesthesia and general anaesthesia on postoperative oxygenation and perioperative mortality. Br J Anaesth 1980;52:49-54

126 McKenzie P, Wishart H, Gray I, Smith G. Effects of anaesthetic technique on deep vein thrombosis: a comparison of subarachnoid and general anaesthesia. Br J Anaesth 1985;57:853-7.

127 McLaren A. Mortality studies. A review. Reg Anesth 1982;7:S172-4.

128 McLaren A, Stockwell M, Reid V. Anaesthetic techniques for surgical correction of fractured neck of femur: a comparative study of spinal and general anaesthesia in the elderly. Anaesthesia 1978;33:10-4.

129 Mellbring G, Dahlgren S, Reiz S, Sunnnegardh O. Thromboemboli complications after major abdominal surgery: effect of thoracic epidural analgesia. Acta Chir Scand 1983;149:263-8.

130 Melsen N, Thorshauge H. Patients experience of epidural anaesthesia and general anaesthesia. Ugeskr Laeger 1987;149:150-2.

131 Merhav H, Rothstein H, Eliraz A, Hana R, Pfeffermann R. A comparison of pulmonary function and oxygenation following local, spinal or general anaesthesia in patients undergoing inguinal hernia repair. Int Surg 1993;78:257-61.

132 Modig J, Malmberg P, Saldeen T. Comparative effects of epidural and general anesthesia on fibrinolysis function, lower limb rheology and thromboembolism after total hip replacement. Anesthesiology 1980;53:S34.

133 Modig J, Maripuu E, Sahlstedt B. Thromboembolism following total hip replacement: a prospective investigation of 94 patients with emphasis on the efficacy of lumbar epidural anaesthesia in prophylaxis. Reg Anesth 1986;11:72-9.

134 Modig J, Karlstrom G. Intra- and post-operative blood loss and haemodynamics in total hip replacement when performed under lumbar epidural versus general anaesthesia. Eur J Anaesthesiol 1987;4:345-55

135 Modig J. Beneficial effects on intraoperative and postoperative blood loss in total hip replacement when performed under lumbar epidural anesthesia. Acta Chir Scand Suppl 1988;550:95-103.

136 Moiniche S, Hjortso N, Blemmer T, Dahl J, Kehlet H. BP and heart rate during postoperative orthostatic stress and continuous epidural analgeia. Reg Anesth 1992;17(Suppl):2.

137 Murakami M. Effect of anaesthesia on endocrine metabolic response to lower abdominal surgery. Masui 1987;36:583-91.

138 Naesh O, Hindberg I, Friis J, Christiansen C. General versus regional anaesthesia and platelet aggregation in minor surgery. Eur J Anaesthesiol 1994:11:169-73.

139 Naesh O, Hindberg I, Friis J, Christiansen C, Pedersen T, Trap-Jensen J, et al. Platelet activation in major surgical stress: influence of combine epidural and general anaesthesia. Acta Anaesthesiol Scand 1994;38:820-5.

140 Nielsen KK, Andersen K, Asbjorn J, Vork F, Ohrt Nissen A. Blood loss in transurethral prostatectomy: epidural versus general anaesthesia. Int Urol Nephrol 1987;19:287-92

141 Nielsen T, Nielsen H, Husted S, Hansen S, Olsen K, Fjeldborg N. Stress response and platelet function in minor surgery during epidura bupivacaine and general anaesthesia: effect of epidural morphine addition. Eur J Anaesthesiol 1989;6:409-17.

142 Nielson WR, Gelb AW, Casey JE, Penny FJ, Merchant RN, Manninen PH Long-term cognitive and social sequelae of general versus regional anesthesia during arthroplasty in the elderly. Anesthesiolog 1990;73:1103-9.

143 Ogata M, Takara H, Tanaka T, Nakamura S, Shigematsu A. The effect of anesthesia on plasma renin and aldosterone: comparison between nitrous oxide-halothane and nitrous oxide epidural anesthesia. Masui 1985;34:1358-63

144 Ogata M, Yanagida K, Takenaka I, Shimozawa K, Shigematsu A. The effect of anesthesia and partial hepatectomy on plasma renin and aldosterone: comparison between nitrous oxide-enflurane anesthesia and nitrous oxide epidural anesthesia. Masui 1988;37:163-8.

145 Pedersen J, Jakobsen B, Egeberg B. Comparison between epidural analgesia and general anaesthesia. Ugeskr Laeger 1986;148:1819-22.

146 Pedersen J, Jakobsen B, Egeberg B. Thromboembolic complications after hip replacement. Ugeskr Laeger 1987;149:1463-6.

147 Poikolainen E, Hendolin H. Effects of lumbar epidural analgesia and general anaesthesia on flow velocity in the femoral vein and postoperative deep vein thrombosis. Acta Chir Scand 1983;149:361-4.

148 Poll J, van Kleef J, Moolenaar A. The influence of epidural anaesthesia on the cortisol response to surgery. A comparison between minor and major surgery in orthopaedic patients. Reg Anesth 1988;13:4.

149 Racle J, Benkhadra A, Poy J, Gleizal B, Gaudray A. Comparative study of general and spinal anesthesia in the elderly female patient undergoing hip surgery. Ann Fr Anesth Reanim 1986;5:24-30.

150 Ravin M. Comparison of spinal and general anaesthesia for lowe abdominal surgery in patients with chronic obstructive pulmonary disease. Anesthesiology 1971;35:319-29.

151 Reinhart K, Foehring U, Kersting T, Schaefer M, Bredle D, Hirner A, e al. Effects of thoracic epidural anesthesia on systemic hemodynamic function and systemic oxygen supply-demand relationship. Anesth Analo 1989;69:360-9.

152 Rem J, Brandt M, Kehlet H. Prevention of postoperative lymphopenia and granulocytosis by epidural analgesia. Lancet 1980;i:283-4

153 Rickford JK, Speedy HM, Tytler JA, Lim M. Comparative evaluation of general, epidural and spinal anaesthesia for extracorporeal shockwave lithotripsy. Ann R Coll Surg Engl 1988;70:68-73.

154 Riis J, Lomholt B, Haxholdt O, Kehlet H, Valentin N, Danielsen U, et al. Immediate and long-term mental recovery from general versus epidural anesthesia in elderly patients. Acta Anaesthesiol Scand 1983;27:44-9.
155 Rosseel P, Marichal P, Lauwers L, Baute L, Hanegreefs G. A hemodynamic study of epidural versus intravenous anesthesia for aortofemoral bypass surgery. Acta Anesthesiol Belg 1985;36:345-63.

156 Rutberg H, Hakanson E, Anderberg B, Jorfeldt L, Martensson J, Schildt B. Effects of the extradural administration of morphine, or bupivacaine, on the endocrine response to upper abdominal surgery. Br J Anaesth 1984;56:233-7.

157 Hakansson E, Anderberg B, Jorfeldt L, Martensson J, Rutberg H, Schild B. Extradural morphine can suppress the endocrine response to upper abdominal surgery. Acta Anaesthesiol Scand Suppl 1983;78:78.

158 Hesselvik F, Brodin B, Hakanson E, Rutberg H, von SH. Influence of epidural blockade on postoperative plasma fibronectin concentrations. Scand J Clin Lab Invest 1987;47:435-40.

159 Ryan P, Schweitzer S, Woods R. Effect of epidural and general anesthesia compared with general anaesthesia alone in large bowel anastomoses: a prospective study. Eur J Surg 1992;158:45-9.

160 Scheinin B, Rosenberg P. Effect of prophylactic epidural morphine or bupivacaine on postoperative pain after upper abdominal surgery. Acta Anaesthesiol Scand 1982;26:474-8.

161 Seeling W, Ahnefeld F, Rosenberg G, Heirich H, Spilker D Cardiovascular changes associated with epidural combined with general anaesthesia as compared to neuroleptanaesthesia. Anaesthesist 1985;34:217-28

162 Seeling W, Ahnefeld F, Hamann H, Heinrich H, Hutschenreiter S, Rosenberg G. Intrarenal aortic bypass operations: influence of neuroleptanaesthesia and continuous epidural anaesthesia on cardiovascular responses during surgery. Anaesthesist 1985;34:417-28.

163 Seeling W, Ahnefeld F, Grunert A, Heinrich H, Lotz P, Rosenberg G, et al. Influence of neuroleptanaesthesia compared with continous epidural plus general anaesthesia on homeostasis and oxygen transport during infrarenal aortic bypass surgery. Anaesthesist 1986;35:80-92.

164 Seeling W, Bruckmooser K, Hufner C, Kneitinger E, Rigg C, Rockemann M. Continuous thoracic epidural analgesia does not diminish postoperative complications after abdominal surgery in patients at risk. Anaesthesist 1990;39:33-40.

165 Seeling W, Bothner U, Eifert B, Rockemann M, Schreiber M, Schurmann W, et al. Patient-controlled analgesia versus epidural analgesia with bupivacaine or morphine after major abdominal operations. No difference in postoperative outcome. Anaesthesist 1991;40:614-23.

166 Seitz W, Lubbe N, Bechstein W, Fritz K, Kirchner E. Effects of anaesthesia and surgery on the hypothalamic hypophyseal adrenocortica system. Anasthesiol Intensivther Notfallmed Scherzther 1985;20:119-24.

167 Sharrock N, Go G. Fibrinolytic activity following total knee arthroplasty under epidural or general anesthesia. Reg Anesth 1992;17(suppl):94.

168 Shir Y, Raja S, Frank S. The effect of epidural versus general anesthesia on postoperative pain and analgesic requirements in patients undergoing radical prostatectomy. Anesthesiology 1994;80:49-56.

169 Simpson PJ, Radford SG, Forster SJ, Cooper GM, Hughes AO. The fibrinolytic effects of anaesthesia. Anaesthesia 1982;37:3-8.

170 Slinger P, Shennib H, Wilson S. Post-thoracotomy pulmonary function: a comparison of epidural versus intravenous meperidine infusions. J Cardiothorac Vasc Anesth 1995;9:128-34.

171 Smeets H, Kievit J, Dulfer F, van Kleef J. Endocrine-metabolic response to abdominal aortic surgery: a randomized trial of general anesthesia versus general plus epidural anesthesia. World J Surg 1993;17:601-7.

172 Stathopoulou T, Melissaki A, Fountoulaki T, Pagouni H, Giala M. Systemic haemodynamic, enzymatic and acid-base changes with the use of tourniquet after general and spinal anaesthesia. Reg Anesth 1992;17(suppl): 181

173 Stenseth R, Bjella L, Berg E, Christensen O, Levang O, Gisvold S. Thoracic epidural analgesia in aortocoronary bypass surgery 1: haemodynamic effects. Acta Anaesthesiol Scand 1994;38:826-33.

174 Stenseth R, Bjella L, Berg E, Christensen O, Levang O, Gisvold S. Thoracic epidural analgesia in aortocoronary bypass surgery II: effects on the endocrine metabolic response. Acta Anaesthesiol Scand 1994;38:834-9.

175 Stjernstrom H, Henneberg S, Eklund A, Tabow F, Arturson G, Wiklund $\mathrm{L}$. Thermal balance during transurethral resection of the prostate. Acta Anaesthesiol Scand 1985;29:743-9

176 Traynor C, Paterson L, Ward ID, Morgan M, Hall GM. Effects of extradural analgesia and vagal blockade on the metabolic and endocrine response to upper abdominal surgery. $\mathrm{Br} J$ Anaesth 1982;54:319-23.

177 Tulla H, Takala J, Alhava E, Hendolin H, Manninen H, Kari A, et al. Does the anaesthetic method influence the postoperative breathing pattern and gas exchange in surgery? A comparison between general and spinal anaesthesia. Acta Anaesthesiol Scand 1992;36:101-5.

178 Tuman K, McCarthy R, March R, DeLaria G, Patel R, Ivankovich A Effects of epidural anesthesia and analgesia on coagulation and outcome after major vascular surgery. Anesth Analg 1991;73:696-704.

179 Tverskoy M, Cozacov C, Ayache M, Bradley E, Kissin I. Postoperative pain after inguinal herniorrhaphy with different types of anesthesia. Anesth Analg 1990;70:29-35.

180 Valentin N, Lomholt B, Jensen JS, Hejgaard N, Kreiner S. Spinal or general anaesthesia for surgery of the fractured hip? A prospective study of mortality in 578 patients. Br J Anaesth 1986;58:284-91.

181 Wallace D, Leveno K, Cunningham F, Giesecke A, Shearer V, Sidawi J. Randomized comparison of general and regional anesthesia for cesarean delivery in pregnancies complicated by severe pre-eclampsia. Obstet Gynecol 1995;86:193-9.

182 Watters J, March R, Desai D, Monteith K, Hurtig J. Epidural anaesthesia and analgesia do not affect energy expenditure after major abdominal surgery. Can J Anaesth 1993;40:314-9.

183 Wattwil M, Sundberg A, Olsson J, Nordstrom S. Thoracolumbar epidural anaesthesia blocks the circulatory response to laryngoscopy and intubation. Acta Anaesthesiol Scand 1987;31:529-31. 
184 Wessen A, Persson P, Nilsson A, Hartvig P. Clinical pharmacokinetics of propofol given as a constant-rate infusion and in combination with epidural blockade. J Clin Anesth 1994;6:193-8.

185 Whelan P, Morris P. Immunological responsiveness after transurethral resection of the prostate: general versus spinal anaesthetic. Clin Exp Immunol 1982;48:611-8.

186 White I, Chappell W. Anaesthesia for surgical correction of fractured femoral neck: a comparison of three techniques. Anaesthesia 1980;35:1107-0.

187 Williams-Russo P, Sharrock N, Mattis S, Szatrowski T, Charlson M. Cognitive effects after epidural vs general anesthesia in older adults: a randomized trial. JAMA 1995;274:44-50.

188 Williams-Russo P, Sharrock N, Haas S, Insall J, Windsor R, Laskin R, et al. Randomized trial of epidural versus general anesthesia: outcomes after primary total knee replacement. Clin Orthop 1996:331:199-208.

189 Worsley M, Wishart H, Peebles Brown D, Aitkenhead A. High spinal nerve block for large bowel anastomosis: a prospective study. $\mathrm{Br} J$ Anaesth 1988;60:836-40.

190 Wust H, Spirgatis WD, Sandmann W, Krian A, Richter O. The effects of different anaesthesic techniques on lactate under the course of aorto-femoral bypass operation. Anasthesiol Intensivmed Notfallmed Schmerzther 1980;15:87-98

191 Yeager M, Glass D, Neff R, Brinck Johnsen T. Epidural anesthesia and analgesia in high-risk surgical patients. Anesthesiology 1987;66:729-36.

192 Zwarts S, Hasenbos M, Gielen M, Kho H. The effect of continuous epidural analgesia with sufentanil and bupivacaine during and after thoracic surgery on the plasma cortisol concentration and pain relief. Reg Anesth 1989;14:183-8.

193 Antiplatelet Trialists' Collaboration. Collaborative overview of randomised trials of antiplatelet therapy. 1. Prevention of death, myocardial infarction, and stroke by prolonged antiplatelet therapy in various categories of patients. BMJ 1994;308:81-106.
194 Go A. Cardiac outcomes after regional or general anesthesia: do we have the answer? Anesthesiology 1996;84:1-2.

195 Sorenson R, Pace N. Anesthestic techniques during surgical repair of femoral neck fractures. Anesthesiology 1992;77:1095-104.

196 Parker M, Urwin S, Handoll H, Griffiths R. General versus spinal/epidural anaesthesia for surgery for hip fractures in adults. In: Cochrane Collaboration. Cochrane Library. Issue 1. Oxford: Update Software, 2000.

197 Rodgers A, Sage D, Futter M, MacMahon S. Attitudes and practices of New Zealand anaesthetists with regard to epidural and subarachnoid anaesthesia. Anaesth Intensive Care 1996;24:79-86.

198 Rigg J, Jamrozik K, Myles P, Silbert B, Peyton P, Parsons R, et al. Design of the multicenter Australian study of epidural anesthesia and analgesia in major surgery: The MASTER trial. Controlled Clin Trials 2000;21:24456.

199 Tarkkila P, Kaukinen S. Complications during spinal anesthesia: a prospective study. Reg Anesth 1991;16:101-6.

200 Tanaka K, Watanabe R, Harada T, Dan K. Extensive application of epidural anesthesia and analgesia in a university hospital: incidence of complications related to technique. Reg Anesth 1993;18:34-8.

201 Horlocker T, McGregor D, Matsushige D, Schroeder D, Besse J. A retrospective review of 4767 consecutive spinal anesthetics: central nervous system complications. Anesth Analg 1997;84:578-84.

202 Ballantyne J, Carr D, deFerranti S, Suarez T, Lau J, Chalmers T, et al. The comparitive effects of postoperative analgesia therapies on pulmonary outcome: cumulative meta-analysis of randomized, controlled trials Anesth Analg 1998;86:598-612.

(Accepted 4 September 2000) 